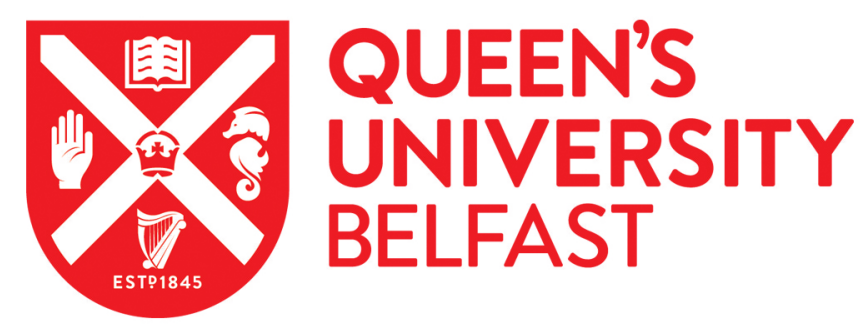

\title{
Innovative processing techniques for altering the physicochemical properties of wholegrain brown rice (Oryza sativa L.) - opportunities for enhancing food quality and health attributes
}

Xia, Q., Green, B. D., Zhu, Z., Li, Y., Gharibzahedi, S. M. T., Roohinejad, S., \& Barba, F. J. (2018). Innovative processing techniques for altering the physicochemical properties of wholegrain brown rice (Oryza sativa L.) opportunities for enhancing food quality and health attributes. Critical Reviews in Food Science and Nutrition. https://doi.org/10.1080/10408398.2018.1491829

Published in:

Critical Reviews in Food Science and Nutrition

Document Version:

Peer reviewed version

Queen's University Belfast - Research Portal:

Link to publication record in Queen's University Belfast Research Portal

\footnotetext{
Publisher rights

(C) 2018 Taylor \& Francis Group, LLC. This work is made available online in accordance with the publisher's policies. Please refer to any applicable terms of use of the publisher.
}

\section{General rights}

Copyright for the publications made accessible via the Queen's University Belfast Research Portal is retained by the author(s) and / or other copyright owners and it is a condition of accessing these publications that users recognise and abide by the legal requirements associated with these rights.

Take down policy

The Research Portal is Queen's institutional repository that provides access to Queen's research output. Every effort has been made to ensure that content in the Research Portal does not infringe any person's rights, or applicable UK laws. If you discover content in the Research Portal that you believe breaches copyright or violates any law, please contact openaccess@qub.ac.uk. 


\section{Innovative processing techniques for altering the physicochemical properties of wholegrain brown rice (Oryza sativa L.) - opportunities for enhancing food quality and health attributes}

Qiang Xia, Brian D. Green, Zhenzhou Zhu, Yunfei Li, Seyed Mohammad Taghi Gharibzahedi, Shahin Roohinejad \& Francisco J. Barba

To cite this article: Qiang Xia, Brian D. Green, Zhenzhou Zhu, Yunfei Li, Seyed Mohammad Taghi Gharibzahedi, Shahin Roohinejad \& Francisco J. Barba (2018): Innovative processing techniques for altering the physicochemical properties of wholegrain brown rice (Oryza sativa L.) opportunities for enhancing food quality and health attributes, Critical Reviews in Food Science and Nutrition, DOI: $10.1080 / 10408398.2018 .1491829$

To link to this article: https://doi.org/10.1080/10408398.2018.1491829

Accepted author version posted online: 11 Jul 2018.

Submit your article to this journal

Џ Article views: 7

View Crossmark data \lceil 
Innovative processing techniques for altering the physicochemical properties of wholegrain brown rice (Oryza sativa L.) - opportunities for enhancing food quality and

\title{
health attributes
}

\author{
Qiang Xia ${ }^{\text {a }}$, Brian D. Green ${ }^{\mathrm{b}}$, Zhenzhou Zhu ${ }^{\mathrm{c}}$, Yunfei $\mathrm{Li}^{{ }^{\mathrm{a}}}{ }^{*}$, Seyed Mohammad Taghi \\ Gharibzahedi $^{\mathrm{d}}$, Shahin Roohinejad ${ }^{\text {e,f, }}$, Francisco J. Barba ${ }^{\mathrm{g}}$
}

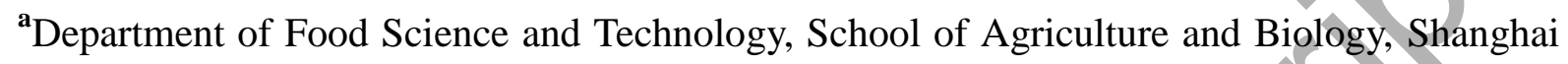
Jiao Tong University, Shanghai 200240, China

${ }^{\mathbf{b}}$ Institute for Global Food Security, Queen's University Belfast, Belfast, Northern Ireland, UK

${ }^{\mathbf{c}}$ School of Food Science and Engineering, Wuhan Polytechnic University, Wuhan 430023, China

'Young Researchers and Elites Club, Lahijan Branch, Islamic Azad University, Lahijan, Iran; ${ }^{\mathbf{e}}$ Department of Food Science and Nutrition, University of Minnesota, St. Paul, MN 55108, USA

${ }^{\mathbf{f}}$ Burn and Wound Healing Research Center, Division of Food and Nutrition, Shiraz University of Medical Sciences, Shiraz, Iran

${ }^{\mathbf{g}}$ Nutrition and Food Science Area, Preventive Medicine and Public Health, Food Sciences, Toxicology and Forensic Medicine Department, Faculty of Pharmacy, Universitat de València, Avda. Vicent Andrés Estellés, s/n, 46100 Burjassot, València, Spain

Running title: Novel processing methods and brown rice

*Corresponding authors: Shahin Roohinejad, PhD, Department of Food Science and Nutrition, University of Minnesota, St. Paul, MN 55108, USA, Tel: +1 612624 2765; Email: sroohine@umn.edu

Yunfei Li, PhD, Department of Food Science and Technology, School of Agriculture and 
Biology, Shanghai Jiao Tong University, Shanghai 200240, People's Republic of China Tel: +86-021-3420691; E-mail: yfli@ sjtu.edu.cn 


\begin{abstract}
Rice is a globally important staple consumed by billions of people, and recently there has been considerable interest in promoting the consumption of wholegrain brown rice (WBR) due to its obvious advantages over polished rice in metabolically protective activities. This work highlights the effects of innovative processing technologies on the quality and functional properties of WBR in comparison with traditional approaches; and it is aimed at establishing a quantitative and/or qualitative link between physicochemical changes and high-efficient processing methods. Compared with thermal treatments, applications of innovative nonthermal techniques, such as high hydrostatic pressure (HHP), pulsed electric fields (PEF), ultrasound and cold plasma, are not limited to modifying physicochemical properties of WBR grains, since improvements in nutritional and functional components as well as a reduction in anti-nutritional factors can also be achieved through inducing related biochemical transformation. Much information about processing methods and parameters which influence WBR quality changes has been obtained, but simultaneously achieving the product stabilization and functionality of processed WBR grains requires a comprehensive evaluation of all the quality changes induced by different processing procedures as well as quantitative insights into the relationship between the changes and processing variables.
\end{abstract}

Keywords: Emerging nonthermal technologies; high hydrostatic pressure; low-pressure plasma; GABA; glycemic index; cereal germination 


\section{Introduction}

Rice is a staple food for more than three billion people and is mainly consumed as polished white rice (PWR) (Park, Lee, \& Choi, 2017). The making of PWR at an industrial scale has a relatively long history with stable and well-established processing procedures. However, PWR manufacturing is still in progress, such as seen by the recent exploitation of commercially available convenience rice (Yu et al., 2017a) and health rice with a reduced glycemic load (Boers, Seijen ten Hoorn, \& Mela, 2015), as well as the introduction of novel profiling techniques for evaluating PWR quality (Pramudya \& Seo, 2018). In the cases of PWR production and consumption, the examined factors are mainly confined to the design and optimization of traditional post-harvest processing stages, including milling, parboiling, quick-cooking, drying, and storage (Atungulu \& Pan, 2014; Boers et al., 2015; Yu et al., 2017a).

PWR consumption provides over $75 \%$ of daily calorie intake from rice particularly in Asian countries (Park et al., 2017). However, recent meta-analyses and cohort studies have observed significant positive relationship between PWR intake and the incidence of type 2 diabetes mellitus (Hu et al., 2012; Nanri et al., 2010), partially explaining the largest number of people with diabetes in China and India, where PWR is the primary source for dietary glycemic load. Over the past few years, the increasing attention has been paid to the substitution of PWR with wholegrain brown rice (WBR) for regulation and control of diabetes, since accumulated results have confirmed the better glycemic control of WBR compared with equivalent PWR (Lee et al., 2016; Nakayama et al., 2017; Wedick et al., 2015; Zhang et al., 2010). Importantly, the dietary substitution process did not substantially improve other metabolic risk factors (Zhang et al., 2011). The anti-diabetic effects derived from WBR are mainly attributed to reduced glycemic response of its available carbohydrate (Zhang \& Hamaker, 2017), as well as potential regulation of other minor bioactive compounds such as 
gamma-aminobutyric acid (GABA) (Adamu et al., 2016; Tian et al., 2011), $\gamma$-oryzanol (Kozuka et al., 2013), and magnesium (Schulze et al., 2007). In addition, apart from anti-diabetic effects, there are many other health benefits which can be obtained by consuming WBR grains, such as antioxidant, anticancer, antihyperlipidemic, antihypertensive, and anticardiovascular effects (Roohinejad et al., 2009a; Roohinejad et al., 2010; Jensen et al., 2004; Lee et al., 2016; Liu et al., 2015; Okarter \& Liu, 2010; Wu et al., 2013b).

The therapeutic activities from WBR are mainly attributed to its higher levels of bioactive phytochemicals and nutrients than PWR, including $\gamma$-oryzanol, GABA, dietary fibers, phenolics, phytosterols, tocotrienols, carotenoids, polyunsaturated fatty acids (omega-3/omega-6), minerals, anthocyanins, proanthocyanidins and vitamin B, among other minor phytonutrients (Cho \& Lim, 2016; Park et al., 2017). Generally, these nutritional substances act synergistically and have protective effects against chronic degenerative diseases (Fig. 1). For example, bioactive compounds present in WBR with antidiabetic effects include GABA, dietary fibers, $\gamma$-oryzanol, and resistant starch (RS) fraction. GABA is a non-protein amino acid and shares various physiological activities in mammals, such as functioning as neurotransmitter in the central nervous system, regulating blood pressure and heart rate, accelerating brain protein synthesis and relieving pain and anxiety (Diana, Quílez, \& Rafecas, 2014; Gan et al., 2017; Poojary et al., 2017). Oral supplements with GABA significantly reduced the glycemic response and improved glucose tolerance in rat model, attributing to its enhanced secretion of insulin from the pancreas (Adeghate \& Ponery, 2002; Tian et al., 2011). Similarly, $\gamma$-oryzanol, a mixture of ferulic acid esters, could also act as a strong secretagogue by directly affecting pancreatic $\beta$-cells to promote glucose-stimulated insulin secretion (Kozuka et al., 2013). As for dietary fiber, clinic trials have established the metabolic link between the high dietary fiber intake and the reduced diabetes incidence (Chandalia et al., 2000; Schulze et al., 2004). The positive effects of dietary fiber on diabetes 
are considered to be closely related to its viscous and/or gel-forming properties as well as the non-digestibility in the upper gut, which thus decrease postprandial glucose response and slow gastric emptying (Weickert \& Pfeiffer, 2008).

Based on the above-mentioned nutritional values and bioactivities, the technology developments and improvements aimed at producing high-quality WBR products have gained attention within the last decade (Table 1). Several reviews have focused on the molecular structure and occurrence of phytochemicals existing in WBR grains or its processing (by)-products (Cho \& Lim, 2016; Goufo \& Trindade, 2014). In addition, others have examined the relationship between selected phytonutrients and potential health outcomes (Park et al., 2017; Perez-Ternero, de Sotomayor, \& Herrera, 2017; Wu et al., 2013b). Although a considerable amount of research has been investigated on WBR grains processing, to the best of our knowledge, there is no any formal systematical review to summarize the effects of different conventional and innovative processing strategies on the quality characteristics and health benefits of WBR samples. Thus, the aim of the present review is to highlight the recent advances in the improvement of quality and functional attributes of WBR products through integrating various processing and pretreatment techniques. Major changes in physicochemical properties, especially those involved in consumers preference, and their association with process parameters as well as the underlying mechanisms are described and discussed. Furthermore, the respective advantages, limitations, and challenges are also compared.

\section{Challenges for WBR production}

To increase wholegrain consumption, the food industry has been endeavoring to enhance the proportion of WBR consumed in existing food products, such as breads (Cornejo et al., 2015; Islam, Ud-Din, \& Haque, 2012), noodles (Baek \& Lee, 2014; Chung, Cho, \& Lim, 2012; Wu 
et al., 2017), pastas (Marti, Seetharaman, \& Pagani, 2010), snacks (Chung, Cho, \& Lim, 2014; Suhem et al., 2015; Suhem et al., 2013b), ethnic puddings and pastries (Gharibzahedi, 2018), and beverages (Koyama \& Kitamura, 2014; Mok, 2006). However, although the incorporation of wholegrain foods into the diet is encouraged in newly issued dietary guidelines (Jones et al., 2017), the amount of WBR consumption remains relatively low because of its limited acceptability as a staple food or a regular part in the diet. The limiting factors are mainly relevant to the histochemical structure of WBR and distribution pattern of bioactive components across the grains.

\subsection{Wholegrain characteristics and its impact on consumer acceptability}

Rice cultivars can be classified into two different subspecies: indica and japonica. According to the histochemical difference (Fig. 2a), the technical terms in relation to rice milling include paddy rice, WBR and PWR (Nambi, Manickavasagan, \& Shahir, 2017). Paddy rice refers to the intact grain after threshing, which is composed of husk, caryopsis coat (bran), endosperm and embryo. Structurally, bran consists of pericarp, seed coat and nucellar cells (De Datta, 1981). For WBR production (Fig. 2b), the husk including palea and lemma is completely removed, whereas the bran is partially milled; the obtained WBR grain is composed of bran layers (6-7\% of its total weight), embryo (2-3\%), and endosperm (about 90\%) (Chen, Siebenmorgen, \& Griffin, 1998). WBR grain is considered as a wholegrain food because of the co-existence of endosperm to pericarp, seed coat and germ, where many physiologically important components are principally localized (Okarter \& Liu, 2010). It is considered that the synergies of the three kinds of anatomical fractions (bran layer, germ, and endosperm) lead to greater health-promoting effects than any single component (Schaffer-Lequart et al., 2017). Nevertheless, the presence of bran and germ is closely linked to the following intrinsic and extrinsic factors responsible for the limited acceptability of 
WBR among consumers. These include: (i) the hard texture perception and chewing palatability due to high fiber content (Gujral \& Kumar, 2003); (ii) the poor water absorption characteristics and prolonged cooking time (Bello, Tolaba, \& Suarez, 2004; Thakur \& Gupta, 2006); (iii) the greater susceptibility to oxidation and off-flavor formation compared with PWR (Goffman \& Bergman, 2003; Lanning \& Siebenmorgen, 2011); (iv) the presence of anti-nutritional factors (e.g. phytic acid and tannin) (Wang et al., 2011); (v) habitual preference for refined products, as well as the unfamiliarity with health benefits of WBR among average consumers.

\subsection{Distribution characteristics of nutritional components}

The extent of bran layer removal is defined as the degree of milling (DOM), closely associated with an overall nutritional value of WBR grain. In general, DOM for WBR grain production tends to span a wide range from 0 to $10 \%$. The reduction in lipids, proteins, antioxidants, dietary fiber, vitamins and minerals increases with the DOM value. For this reason, the DOM is often limited to below $2 \%$ (Nambi et al., 2017).

Quantitative information related to the effects of DOM on nutritional and physicochemical characteristics of WBR is summarized in Fig. 3. The loss of protein, minerals, free phenolics and flavonoids during the milling process might be reached up to $28.6 \%, 84.7 \%, 65.1 \%$ and 72.3\%, respectively (Lamberts et al., 2007; Liu et al., 2015). Among essential minerals, the milling process resulted in $25-84 \%$ of iron loss depending on rice genotypes (Prom-u-thai et al., 2007). In the case of pigmented rice, the milling process from paddy grain to PWR was reported to remove more than $90 \%$ of free phenolics from black and red rice grains (Paiva et al., 2016). These quantitative results have clearly confirmed that a substantial proportion of nutrients exist in the fractions of outer bran and rice germ. 
On the other hand, however, as DOM increases, a softer oral palatability and improved cooking index can be achieved, as outer rice bran (RB) possesses a chewy texture and compacted structure which hinders the penetration of water into the interior layers of rice caryopsis. Thus, a negative relationship between sensory characteristics and nutritional values of WBR can be concluded. Furthermore, although the outer bran fraction and germ have higher contents of bioactive components, the co-existence of oxidative enzymes including lipoxygenase and peroxidase, and the resultant off-flavor, as well as anti-nutritional factors such as phytic acid and tanning can largely compromise the desirability to consumers. In spite of their antioxidant and anticancer properties, phytate and tanning compounds are considered to be anti-nutritional factors as a whole (Coulibaly, Kouakou, \& Chen, 2011; Torkamani, Razavi, \& Gharibzahedi, 2014).

Overall, all these distinct characteristics intrinsically require the application of innovative processing strategies in WBR production for improving the balance between sensory characteristics and nutritional values. On one hand, overcoming those obstacles involved in storability and textural properties is the major prerequisites for promoting WBR consumption. On the other hand, minimizing the loss of bioactive components during processing, particularly those heat-sensitive substances, is another great concern for the selection of optimum processing procedures and parameters.

\section{Multiple strategies to improve WBR quality and functionality}

Over the past few years, there have been several studies conducted to minimize the limitations of WBR using biological approaches and innovative processing technologies and their combined patterns (Fig. 4). Some of the advantages and limitations of these techniques are summarized in Table $\mathbf{1}$. 


\subsection{Bioprocess-based approaches}

Bioprocessing of WBR grains includes germination, fermentation and the use of hydrolytic enzymes at various processing stages.

\subsubsection{Germination}

Germination is a complex physiological process that is traditionally used as an economical method for the preparation of sprouted seeds, such as soybean, mungbean sprouts, etc. There is a great interest in developing cereal germination mainly due to the enhancement in nutritional and functional properties during the process and resultant health outcomes (Roohinejad et al., 2011; Roohinejad et al., 2009b; Hübner \& Arendt, 2013; Hahm, Park, \& Martin Lo, 2009; Huang, Cai, \& Xu, 2014). The differences between germinated and non-germinated grains have been widely studied in terms of physicochemical and sensorial properties of WBR-derived products (Table 1). Short-period germination is capable of softening texture, improving palatability, and shortening cooking time as well as reducing anti-nutritional factors (Jiamyangyuen \& Ooraikul, 2008; Liang et al., 2008; Sirisoontaralak et al., 2015; Watchararparpaiboon, Laohakunjit, \& Kerdchoechuen, 2010).

During germination, significant changes in the chemical composition of WBR grains can be observed, as summarized in Table 2. Although the final contents of chemical substances in WBR may be influenced by rice genotypes and germination conditions (e.g., temperature, time, $\mathrm{pH}$, and culture solution composition), there are still some general patterns found for the variation of macro- and micro-molecular nutrients within the process. For instance, the starch content was reported to decrease by the increased hydrolytic activities of the enzymes such as $\alpha$-amylase and $\alpha$-glucosidase, resulting in the accumulation of simple sugars (Saman, Vázquez, \& Pandiella, 2008; Sibian, Saxena, \& Riar, 2017). Regarding protein, it shows an overall increasing tendency as a result of the synthesis of new proteins and enzymes mainly 
in the GBR sprouts (Kim et al., 2012; Moongngarm \& Saetung, 2010; Sibian et al., 2017). Moreover, anti-nutritional compounds in WBR, such as phytic acid and oxalate, can be greatly reduced due to the activation of related hydrolases across the entire germination process (Bartnik \& Szafrańska, 1987; Liang et al., 2008; Nissar et al., 2017). Biochemical and metabolic activities during germination process result in the significant accumulation of bioactive components, such as dietary fibers, GABA, folate, vitamins, $\gamma$-oryzanol, flavonoids and phenolic acids (Table 2). All these changes within the grains, associated with macro- and micro-nutrients, are regulated by various metabolic pathways and also interacted with each other (Pramai et al., 2017; Wang et al., 2016). Biochemical activities of specific pathways may vary at different germination periods and result in the fluctuation of some metabolites during the process. As in the case of the transformation of phenolic compounds, soluble fractions of phenolic acids were synthesized at initial stage of germination while insoluble fractions were mainly produced at later stage of germination, which was due to the difference in the activities of key enzymes at different germination periods, such as phenylalanine ammonia-lyase and cell wall peroxidase (Cho \& Lim, 2018).

Although the effects of germination process on the physicochemical and nutritional properties of GBR have been extensively reported, the molecular mechanisms of action are still not very clear. For example, to explain the reasons for the increased in vitro starch digestibility derived from germination, changes in molecular and crystalline structures have been described by microstructural characterization approaches (You et al., 2016). The authors concluded that the increased susceptibility of starch to the enzymatic attack was related to the pores and pins formed on the surface of starch granules, reduced crystallinity and increased short-chains amylopectin. However, regarding the distribution of starch molecular weight, the results were controversial. You et al. (2016) observed a reduced average molecular weight attributing to the decomposition of some amylopectin molecules during the germination 
process; and interestingly, they also found a slightly higher average branch chain length of amylopectin after germination. In contrast, according to Wu et al. (2013a) and Li et al. (2017), there were no significant differences observed in the molecular weight between raw and germinated grains starch, including both weight-average molecular weight $(\mathrm{Mw})$ and number-average molecular weight (Mn).

It should be noted that a long-period soaking process during the germination may cause the loss of micronutrients (e.g. minerals, soluble antioxidants, and aroma-active compounds) due to the leaching out into the aqueous phase. Furthermore, the microbiological spoilage during steeping stage is one of the biggest challenges for sprouts production, because bacteria, molds and yeasts can proliferate quickly owing to favorable temperature and nutritional conditions. For overcoming these problems, thermal sterilization such as hot-water $\left(90{ }^{\circ} \mathrm{C} / 90\right.$ s) and dry-heat treatments $\left(50^{\circ} \mathrm{C} / 17 \mathrm{~h}\right)$ were suggested to inactivate microbial growth (Bari et al., 2009; Bari et al., 2011). Nevertheless, the seed germination performance could be compromised greatly.

Several studies reported the feasibility of using electrolyzed water (EW) as a culture solution in GBR production instead of tap water (Table 1). Generally, EW is produced via electrolyzing dilute salt solutions or hypochlorous acid. EW has been authorized as an antimicrobial agent in Japan since 2002, due to its confirmed biological safety and environmental friendliness at effectively bactericidal levels (Huang et al., 2008). Disinfection effectiveness originating from EW treatments was closely related to its high oxidation-reduction potential and the presence of free chlorine, causing the unbalanced metabolic fluxes and energy production as well as the damage of cell wall/membranes of microorganisms (Huang et al., 2008; Liao, Chen, \& Xiao, 2007; Osafune, Ehara, \& Ito, 2006; Wang, Xia, \& Li, 2017a, 2017b). Interestingly, apart from efficiently inhibiting microbial proliferation, the use of EW as a washing and soaking agent had the capability to promote 
WBR sprouting and GABA accumulation (Li et al., 2015; Liu et al., 2013; Rui et al., 2011), indicating that metabolic activities and biochemical pathways of plant cells can be affected by EW during the germination. However, the specific mechanisms relating physicochemical attributes to the variation of metabolic pathways and biochemical reactions for EW-mediated germination process need to be further clarified.

\subsubsection{Fermentation}

WBR fermentation is used as a supplementary technique to utilize substantial bioactive components in the grains by producing WBR-based foods, such as beverages, porridges, vinegar and bread (Table 1). Fermenting strains include yeast, lactic acid bacteria (LAB), Monascus sp. and Aspergillus oryzae. Powerful metabolic activities and enzymatic transformation derived from microorganisms during WBR fermentation process help to enhance the bioavailability of micronutrients as well as to reduce the anti-nutritional factors. According to Ilowefah et al. (2015), inoculating the yeast to WBR flour exerted significant positive effects on functional properties when fermented at a moderate acidity ( $\mathrm{pH} 5-6$ ), which achieved the increase of protein, insoluble fiber, soluble fiber, minerals, phenolics, total antioxidants, RS, and vitamins $\mathrm{B}$ and $\mathrm{E}$ as well as the reduction of phytate. Simultaneously, physicochemical characteristics of WBR flour, including foaming capacity, foaming stability, oil holding capacity, gelatinization temperatures, enthalpy, and whiteness can be largely influenced by fermentation. These changes could be regulated by modifying fermentation process parameters, such as temperature, time and yeast inoculum concentration.

In addition, the formation of organic acids and volatile flavoring compounds as well as the decomposition of polysaccharide into simple sugars by microbial strains and hydrolytic enzymes can endow the final products with pleasant taste presenting slightly acid and sweet 
(Li, Dai, \& Lu, 2007). Based on the quantification results by liquid chromatography/tandem mass spectrometry (Ogawa et al., 2017), it has been confirmed that esterase activities from $A$. oryzae enhanced the liberation of bound phenolic acids and significantly increased hydroxybenzoic acids. This process allows the improvement of food functionality as free forms of phenolic compounds are inclined to represent higher bioactivities than the corresponding polysaccharide-bound forms (Subba Rao \& Muralikrishna, 2002). Increasing evidence of in vitro and in vivo researches has suggested that the fermented WBR products have multiple preventive and therapeutic effects against carcinogenesis, oxidative stress, inflammation and glucose homeostasis disorders (Chung, Rico, \& Kang, 2014; Kuno et al., 2015; Onuma et al., 2015). Despite a promising tool to produce WBR-based products with desirable organoleptic, nutritional and functional attributes, fermentation process involves in obvious transformation in the form of food matrix and in most cases, the WBR flour rather than integral grains is used as the fermenting substrate for optimum metabolic activity of the inoculated microbes, which may limit the application of fermentation in WBR processing.

\subsubsection{Enzyme-based approaches}

Enzymatic action occurs for the specific transformation of targeted molecules, and this feature is currently utilized to engineer food structure for obtaining novel physical and functional attributes (Zeeb, McClements, \& Weiss, 2017). One of major advantages of enzymatically treating WBR grains is to achieve better textural and cooking attributes by degrading bran layers using cellulase enzymes or related complex enzymes. According to Das, Banerjee and Bal (2008a), applying xylanase and cellulase to WBR grains before cooking resulted in the easier diffusion of water into the kernel, thus reducing cooking time. More importantly, major nutrients including phenolic compounds, minerals, thiamine, niacin, and pyridoxine were largely maintained after enzymatic treatments. In this sense, the substitution 
of mechanical milling with enzymatic polishing was proposed for the production of rice products (Das et al., 2008b). To reduce abrasive perception from bran layer, protease pretreatments were also introduced to soften WBR-based bread through decreasing the hardness and chewiness (Renzetti \& Arendt, 2009). Interestingly, apart from shortening the soaking time, enzymatic pretreatments with xylanase and cellulase before germination were reported to improve germination yields and GABA levels (Jia et al., 2016).

Combining mechanical treatments with the use of enzymes was proposed to maximize the advantages of enzymatically processed WBR. Zhang et al. (2015a) evaluated the applicability of ultrasonic treatment followed by the cellulase solution soaking, who observed more obvious improvement of cooking and sensory attributes such as textural quality and taste value compared with purely using enzymatic processing. This was attributed to the cracks formed on the surface of impervious compact fibrous layer after ultrasonic treatments, which favored the penetration of enzymes into the interior and accelerated enzymatic degradation of RB. In the case of extrusion, it was found that the addition of thermostable $\alpha$-amylase during the extrusion of WBR flour greatly increased the retention of phenolics and free flavonoids (Zeng et al., 2017; Zeng et al., 2018), which became more prominent when the enzyme levels were increased. However, the specific mechanisms about the relationship between high reducing sugar contents and the retention of antioxidant compounds were not clarified.

\subsection{Innovative nonthermal processing techniques}

\subsubsection{High hydrostatic pressure}

High hydrostatic pressure (HHP), also named high pressure processing (HPP), is regarded as the most successfully commercialized innovative nonthermal approach (Misra et al., 2017a). This technique employs water as the medium to transmit pressure (generally in the range of 100-600 MPa, at an industrial level) throughout food system aiming to produce 
organoleptically high-quality, microbiologically safe and nutritionally intact products. Application of high pressure (HP) inactivates microorganism and deteriorates enzymes but it has a minimal impact on low-molecular-weight compounds such as vitamins, flavoring molecules and antioxidants (Balasubramaniam, Martínez-Monteagudo, \& Gupta, 2015; Barba, Esteve, \& Frígola, 2012; Barba et al., 2017a; Huang et al., 2017; Oey et al., 2008). Recent research focuses regarding the use of high pressure are more put on the exploitation and development of health foods, based on its capability to promote the bioaccessibility/bioavailability of bioactive components, to reduce food additives and salt and also to inhibit the formation of contaminants (Barba et al., 2017b; Barba et al., 2015b; Pottier, Villamonte, \& de Lamballerie, 2017).

The rice ingestion may cause allergic disorders including asthma and dermatitis, mainly associated with the allergenic properties of albumin and globulin (Estrada-Girón, Swanson, \& Barbosa-Cánovas, 2005). The application of HHP in rice products was initially driven by its potential to reduce allergenicity relying on the HP-induced partial destruction in cell integrality and protein structure (Kato et al., 2000; Zhang et al., 2015b). After pressurization at 100-400 MPa for $30 \mathrm{~min}$, the significant solubilization of allergenic proteins in rice was observed, resulting in the release of the allergens into the solution (Kato et al., 2000). By combining HHP treatments and protease, the release process of rice allergens was promoted, resulting in their complete elimination from grains.

Recent applications of HP technique in rice have been concentrated on its ability to achieve quick cooking and good texture (Boluda-Aguilar et al., 2013), and these HP-induced changes in rice qualities are urgently demanded for WBR grains. The feasibility of using HP treatment combined with various processing parameters and patterns, in relation to their effects on sensory and nutritional characteristics of final processed products have been investigated (Table 1). 
It has been well-known that HP treatments can accelerate water uptake kinetics by enhancing the hydration of cereal biopolymers such as starch and protein (Knorr, Heinz, \& Buckow, 2006). Pre-soaking is generally used to soften the grain and to facilitate the starch gelatinization during the cooking process, particularly for the rice with poor water absorption. In this line, Ahromrit, Ledward, and Niranjan (2006) investigated HP-induced water uptake characteristics of glutinous rice (polished form), concluding that the equilibrium moisture content (EMC) and water uptake rates increased with pressure intensities (100-600 MPa) and temperature $\left(20-70{ }^{\circ} \mathrm{C}\right)$. Regarding WBR grains, however, the values for EMC fluctuated within the applied pressures of $100-500 \mathrm{MPa}$, which was related to the histochemical difference and the formed cracks at the RB surface (Yu et al., 2015).

Yu et al. (2015) reported that the HP-mediated pre-soaking contributed to shortening about $60 \%$ of the cooking time of WBR grains; and more importantly, the palatability was largely improved due to the damaged structure of pericarp and aleurone layer under pressures. These changes in cooking and textural attributes were greatly dependent on the applied pressure intensities (holding times and pressures) and processing patterns. For example, the more obvious structural damage of RB under two-cycle HP processing led to a lighter color and a softer texture for cooked WBR grains, compared with the one-cycle mode based on same processing duration (Yu et al., 2017b).

Given the high nutritional value of germinated cereals, HP processing has been applied to enhance the utilization efficiency of nutrients in GBR grains, particularly bioactive micronutrients. Through an in vitro digestion model, it was revealed that HP treatments (100-500 $\mathrm{MPa} / 10 \mathrm{~min})$ greatly improved the in vitro bioaccessibility of micronutrients including GABA, indispensable amino acids, and antioxidant compounds as well as the starch digestibility, whereas bioaccessible minerals varied depending on the pressures and element species (Xia et al., 2017b; Xia et al., 2017c). For enhancing biochemical changes 
under HP, WBR grains were germinated and immediately kept under HP conditions for 24-48 h (Kim et al., 2015a, 2017; Kim et al., 2015b). The pressures were limited within moderate ranges varying from 10 to $100 \mathrm{MPa}$, mainly used to maintain the enzyme activities and to induce partial cell decompartmentalization for the easier accessibility of enzymes to the targeted substrates in GBR matrix. Thus, the substantial bioconversion reactions responsible for the accumulation of bioactive compounds, including polyphenols, GABA, arabinoxylans, flavonolignans, and phenolic acids and vitamin E, was significantly promoted at post-germination stages, depending on the applied pressures.

It should be noted that the above-mentioned researches were mainly focused on the changes after immediate HP treatments. However, recent results suggested that the direct HP processing on WBR grains could cause some deleterious outcomes, including the acceleration of lipid hydrolysis and oxidation kinetics as well as the presence of browning compounds during the prolonged storage (Xia \& Li, 2018b; Xia et al., 2017d). To avoid these negative effects, HP pretreatments prior to the germination could be a potential strategy for improving functional and quality properties of WBR grains, because through this combined process the increased GABA content, the reduced lipid hydrolysis and oxidation, and the stabilized color development during storage process were simultaneously achieved (Xia \& Li, 2018a; Xia, Wang, \& Li, 2018). These observations could be associated with the modifications of metabolic pathways during malting due to HP stress effects. Particularly, when plants like WBR grains are stressed by HP, some plant secondary metabolites may be accumulated through adaptive response during their germination, similar to what happened under other abiotic stress factors (e.g., salt, drought and anoxia) (Barba et al., 2017c). In this sense, biological implications together with their unique biochemical and molecular effects behind HP can be exploited for the modulation of food functionality and quality characteristics. 


\subsubsection{Pulsed electric fields (PEF)}

As a newly employed nonthermal technology, PEF is applied to various foodstuffs through transient electronic pulses $(\mu \mathrm{s} \sim \mathrm{ms}$ ) produced from two high-voltage electrodes, with an electric field strength varying from 0.1 to $80 \mathrm{kV} / \mathrm{cm}$ (Oey et al., 2016; Barba et al., 2015a). One of the major applications of PEF processing is inactivation of a wide range of microorganisms and quality-related enzymes with minimum effect on sensory and nutritional properties (Barba et al., 2018; Barba et al., 2015a; Silva et al., 2016). Qian et al. (2014) have examined the contribution of different PEF parameters to lipase inactivation in WBR samples, finding that the inhibitory effect was positively related to the frequency $(200-1000 \mathrm{~Hz})$, pulse width (3-15 $\mu \mathrm{s})$, residence time (1-9 s), and voltage (3-15 V), while it was negatively influenced by the material thickness $(5-25 \mathrm{~mm})$. Moreover, voltage was found to be the main factor influencing microbial inactivation followed by pulse width and frequency (Gabrić et al., 2018).

PEF is also used as a non-conventional extraction tool for recovering functional components from plant materials since electronic pulses can improve membrane permeabilization by modifying membrane microstructure, thus enhancing the mass transfer rate (Roohinejad et al., 2014a, Roohinejad et al., 2014b; Puértolas \& Barba, 2016; Puértolas, Koubaa, \& Barba, 2016; Zhu et al., 2016). As expected, when applied to WBR samples, PEF-assisted solvent extraction increased the yields of many bioactive components including polyphenols, phenolic acids, $\gamma$-oryzanol tocopherols as well as saturated and unsaturated fatty acids, and therefore corresponded to higher antioxidant activity and cytotoxic activity against colorectal cancer cells compared with the extract obtained from PEF-untreated samples (Quagliariello et al., 2016). Considering that the by-product of WBR and PWR production is a source containing considerable amounts of phytochemicals, the integration of PEF pretreatment into the solvent extraction of $\mathrm{RB}$ could be a promising strategy to improve the 
recovery rates of bioactive components. To our knowledge, only few studies examined the applicability of PEF for WBR processing, and little information about the changes in sensory attributes and biological effects of WBR grains has been reported, particularly in terms of PEF-derived electrochemical effects and the possible metabolic response after electric stimulus for GBR (Dymek et al., 2012; Misra et al., 2017b).

\subsubsection{Cold plasma}

Cold plasma technology has drawn considerable attention from food sectors in the last decade owing to its large potential for the safe and sustainable food production (Bourke et al., 2018; Misra et al., 2017a; Misra et al., 2017b). Plasma refers to an ionized gas mixing positive and negative ions, photons, electrons and molecules, overall representing nearly no net electrical charge; and the generation of plasma involves in the ionization of neutral gas under different electromagnetic fields with sufficient power (Misra et al., 2016). Cold plasma is initially required to generate at the low-pressure condition, and recent advances in plasma source manufacturing techniques allow the use of plasma technique under atmospheric pressure, which is rather important for wide application in food processing (Misra et al., 2016; Segat et al., 2016). Generally, relying on the plethora of chemically active species produced during gas ionization, plasma treatment shows the capability to induce chemical modification to food components and to inactivate deteriorative enzymes and microorganisms (Bourke et al., 2018; Misra et al., 2016). Based on this fact, the practical applicability of cold plasma in WBR processing has recently been explored by several studies.

After plasma treatments (1-3 kV/1.2 mA/30 min), morphological observation showed the presence of etching patterns on the surface of WBR bran, causing easy water absorption and reduction in cooking time and hardness (Chen, 2014; Chen, Chen, \& Chang, 2012). These results have recently been confirmed by Thirumdas et al. (2016), using low-pressure plasma 
technique. Even though the plasma-processed samples were subjected to a three-month storage, the processing effects on cooking properties (cooking time and hardness) were still significant (Chen et al., 2015a). This kind of stability in plasma-induced physicochemical modification is extremely meaningful because the processed samples must be subjected to a storage process before consumption. Therefore, a further study was performed to examine plasma effects on WBR grains during the storage (Chen et al., 2015a), showing the decrease in lipid hydrolysis and oxidation in plasma exposed samples owing to the inhibitory effects on the activities of the enzymes such as lipase and lipoxygenase. In addition, a significant reduction in $\alpha$-amylase activity was also observed in plasma-treated samples during storage. The plasma-induced inactivation effects on enzyme activities were mainly attributed to the spatial changes of enzyme structures and chemical modification on individual amino acids by ionized gas, in relation to enzyme varieties, plasma treatment parameters (e.g., voltages, frequency, and exposure mode) and types of plasma sources (Misra et al., 2016).

Inactivation effects can be enhanced by enlarging plasma power and extending treatment time, but the possibility of compromised sensory characteristics derived from increased plasma exposure should be considered. For example, WBR cereal bars were subjected to the radio-frequency power of $40 \mathrm{~W}$ for $25 \mathrm{~min}$ to completely inhibit the growth of A. flavus during storage (Suhem et al., 2013a). However, by applying these processing conditions, the odor like cooking rice was produced and thus reduced consumer's acceptability. To maintain an acceptable odor and inhibit the microorganisms efficiently, the exposure time of cold atmospheric plasma was reduced to 20 min (Suhem et al., 2013a).

On the other hand, plasma-induced biological effects were also used to improve quality characteristics and functionality of WBR products. Chen et al. (2016) investigated the effects of low-pressure plasma pretreatments $(1-3 \mathrm{kV} / 10 \mathrm{~min})$ prior to the WBR germination on seed vigor and functional components. It was found that plasma shock contributed to the 
significant increase in germination rates, seedling length, GABA, total phenolic compounds, total antioxidant capacity and $\alpha$-amylase activity in GBR samples, presenting more prominent enhancement with increased plasma voltages in the range of $1-3 \mathrm{kV}$. When the plasma voltage was kept at $80 \mathrm{kV}$, the germination rates of wheat remained unchanged for 5-min treatment, whereas extending the processing time to 20 min greatly decreased the seed sprouting capability, regardless of exposure mode (Los et al., 2018). These results demonstrated that mild plasma treatments could be used as a successful strategy for enhancing the functionality of germinated products.

\subsubsection{Ultrasound}

Ultrasound is a well-established technique and its novel applications in food industry related to the analysis, extraction, quality control, and processing have been persistently exploited in the last two decades (Awad et al., 2012; McClements, 1995; Zhu et al., 2016). In the ultrasonication process, ultrasonic waves are capable to create an alternating compression and expansion in a liquid medium in the form of cavitation bubbles, thus resulting in a series of physicochemical effects (Roselló-Soto et al., 2015; Zinoviadou et al., 2015). According to the power density, ultrasound waves can be grouped into low-intensity (LIU) and high-intensity types (HIU). The HIU power is generally in the range of $10-1000 \mathrm{~W} / \mathrm{cm}^{2}$, which can induce obvious structural disruption and chemical reactions, so that HIU treatments may promote lipid hydrolysis and oxidation during the storage process (McClements, 1995; Xia et al., 2017d). So far, the ultrasonic application in WBR processing mainly focused on the use of LIU, the power of which is typically below $1 \mathrm{~W} / \mathrm{cm}^{2}$ and considered as a non-destructive. However, due to its limited effects on surface structure of RB, the cooking attributes of WBR grains may not be obviously affected by LIU, as observed by Cui et al. (2010), who reported the decrease of cooking time from 39.6 to $37 \mathrm{~min}$ for the samples ultrasonically treated at 
$25{ }^{\circ} \mathrm{C}$. To enhance ultrasonic effects, Park and Han (2016) added a soaking process $(2-8 \mathrm{~h})$ prior to ultrasound treatments $\left(400 \mathrm{kHz} / 25-50{ }^{\circ} \mathrm{C} / 30-60 \mathrm{~min}\right)$, which greatly promoted water uptake ratio during processing. After ultrasound treatments $\left(50^{\circ} \mathrm{C} / 60 \mathrm{~min}\right)$, the fully hydrated samples caused the reduction of cooking time and softening of WBR texture, which showed similar hardness to that of cooked milled rice. Nevertheless, a long-period soaking could result in the loss of micronutrients, particularly water-soluble vitamins such as thiamin, riboflavin and niacin.

Ultrasound application for biotechnological purposes has been extensively reported as an effective tool for regulating and controlling bioprocesses, including fermentation, enzymatic transformation, seed germination and plant growth (Hashemi et al., 2018; Mota et al., 2017; Ojha et al., 2017; Teixeira da Silva \& Dobránszki, 2014). Ultrasonic effects on the course of these bioprocesses in mild conditions are closely associated with the improved mass transfer, activated enzyme activities as well as modified cell permeability and cellular metabolism. Particularly, ultrasonic vibration on seeds has shown the capability to improve seedling vigor and physiological features of grown plants (Chen et al., 2013; Wang et al., 2012). In this sense, ultrasound has recently been used for producing germinated foods with improved edibility and nutritional quality. As for WBR, application of ultrasounds accelerated the germination rates and sprouts length compared with the untreated GBR samples and simultaneously enhanced the starch hydrolysis due to the amylase activation (Ding et al., 2018a). Moreover, due to the abiotic stress, pretreatments of WBR with ultrasound waves resulted in GABA accumulation during the sprout growth (Ding et al., 2018a). Metabolomics analysis suggested that many metabolites in GABA-shunt pathway responsible for regulating GABA formation were largely modified as a response to ultrasound stress (Ding et al., 2018b). 


\subsubsection{Irradiation}

Food irradiation is mainly used for sanitary purposes relying on its ability to inactivate living cells of microbes and insects, as is the case for the disinfestation of vegetables, cereals, herbs, spices and fruits; and it also inhibits sprout growth of garlic and potato (Kume et al., 2009). Although the safety of irradiated foods has been confirmed by many international expert groups, misinformation and concern about their safety among consumers are still the limiting factors to implement this technique in the food industry (Farkas \& Mohácsi-Farkas, 2011). Generally, gamma irradiation caused no obvious change in the contents of starch, amylose, protein and lipid after immediate treatments (Sung, 2005; Wu et al., 2004). However, the microstructure of biological macromolecules and physicochemical attributes, such as color parameters, texture, viscosity, and antioxidants, can be influenced by gamma irradiation, particularly after prolonged storage. Several literatures have reported the effects of irradiation treatments on phenolics content and antioxidant activity of WBR grains (Shao et al., 2013; Sultan, Wani, \& Masoodi 2018; Zhu et al., 2010). It was found that gamma irradiation could affect covalent bonds between bound phenolics and sugars, thus leading to an overall increase in phenolic contents and antioxidant capability with increased irradiation doses. However, high dose of gamma irradiation may induce browning phenomenon and off-flavor, thus reducing consumer acceptability. The color changes induced by gamma irradiation could be attributed partially to the formation of dark spots in starch granules, although irradiation treatments also favored the inhibition of starch aging during storage (Chen et al., 2015b). On the other hand, the reduction in irradiation dose can compromise the efficiency of disinfection and stabilization. Therefore, process parameters for gamma irradiation treatments of WBR should be optimized to achieve extension of products shelf life matched with good sensory features. 
Ultraviolet (UV) radiation is also used as a nonthermal treatment for improving products stability (Gharibzahedi et al., 2018). Jongyingcharoen and Cheevitsopon (2016) investigated the effect of UV treatments (254 $\mathrm{nm}$ wavelength/30-60 $\mathrm{min}$ ) on the microbial inhibition of cooked GBR grains. Although UV delayed the growth of aerobic bacteria, yeast and mold during storage, the samples treated for $30 \mathrm{~min}$ and $60 \mathrm{~min}$ have showed the total colony counts exceeding the microbiological criterial at day 2 and 4 of storage, respectively. UV had no influence on color and hardness of cooked GBR samples but caused the degradation of GABA. These results suggested that single UV irradiation was hard to achieve the significant improvement of WBR storability and quality.

\subsection{Heating pretreatments and drying techniques}

For WBR production, traditional heating treatment mainly refers to parboiling process, which is designed to improve textural properties and storage stability (Fig. 2). For the same purpose, parboiling was also employed for GBR samples (Cheevitsopon \& Noomhorm, 2015; Liu et al., 2017). Though trials have been made to optimize parboiling procedure and conditions for improving quality and functional characteristics of WBR products (Hu et al., 2017; Kwofie \& Ngadi, 2017; Patindol, Newton, \& Wang, 2008b), the general parboiling process includes three essential steps: soaking at $60-80{ }^{\circ} \mathrm{C}$ for a duration ranging from several hours to days; steaming (100-120 ${ }^{\circ} \mathrm{C} / 0 \sim 30 \mathrm{~min}$ ); and drying which may continue up to several days at $25-40{ }^{\circ} \mathrm{C}$. Therefore, this method remains to be considered as a time-consuming, laborious and energy intensive. In recent years, for the purposes of extending shelf life and enlarging products availability, new types of heating and drying techniques have been applied to WBR samples, including infrared (Ding et al., 2015), high-temperature fluidization techniques (Jaisut et al., 2009), fluidized bed drying (Cheevitsopon \& Noomhorm, 2011), microwave irradiation (Zhong et al., 2013), extrusion (Zhang et al., 2018), and puffing (Mir et al., 2016). 
High temperature heating significantly inactivates deteriorative enzymes and stabilizes WBR grains during the storage, but also causes some negative effects such as degradation of bioactive components (e.g., GABA, free phenolics, flavonoids, vitamin) and browning (Chalermchaiwat et al., 2015; Mir et al., 2016; Zhang et al., 2018). For example, compared with cold extrusion, hot extrusion has wider applications in the food industry, but it is a thermomechanical process where food materials are subject to high temperature, shear forces and pressures for a short time, thus causing the loss of thermally sensitive bioactive components (Alam et al., 2016; Kumar et al., 2017). On the other hand, the impact of heating and drying techniques on WBR is based on their effects on definite commonly-used indices such as texture, lipid degradation, taste, cooking properties, and major functional components. For evaluating the overall processing effects of these newly-tailored techniques, not only single-response studies, but also multiple-response studies which rely on both targeted and non-targeted approaches should be integrated to give comprehensive information relating to the food quality modification (Grauwet et al., 2014).

\section{Concluding remarks}

Overall, increasing strategies for improving sensory, nutritional and functional properties, as well as storage stability of WBR products have been developed and optimized in the last decade, due to the importance of WBR consumption to health and longevity. Among the techniques employed, nonthermal innovative processing approaches including HHP, cold plasma, PEF and ultrasound can shorten cooking time and soften texture because of the changes in water uptake characteristics and bran structure. Compared with traditional heating and drying techniques, one of the remarkable advantages for WBR processing via these nonthermal procedures is to maintain and improve the bioactivities of WBR samples. Possible mechanisms linked to the increase in bioactive compounds using nonthermal 
processing could be attributed to the process-induced modification of the following factors: (i) enzyme activities, (ii) the intracellular microenvironment $(\mathrm{pH}$, metal distribution, molecular interaction, etc.) and microstructure, (iii) metabolic pathways during bioprocess, and (iv) the extractability. The immediate increase in the content of bioactive components after treatments could be the result of their enhanced extractability. However, contribution of factors (i) and (iv) should be specially considered while examining the variation in targeted molecules during processing, preservation and storage. Furthermore, application of nonthermal techniques as shock pretreatments for GBR germination can also induce a series of biological effects which has the potential to modulate the quality and functionality of final products. Since only few investigations have been conducted on nonthermal approaches mediated germination, the parameters related to both germination process and pretreatment techniques should be matched and optimized for maximizing product quality and functionality, and novel combination patterns should be explored, such as the combination of electrochemical stimulus and WBR germination. To better understand the mechanisms behind the physicochemical properties and biological responses derived from innovative techniques, omics approaches including metabolomics and proteomics should be introduced.

\section{Acknowledgements}

Qiang Xia and Yunfei Li were financially supported from the National Key Technology Research \& Development Program of China under Grant No. 2014BAD04B08 for the preparation of the article. Qiang Xia and Brian D Green were also supported by the UK-China Joint Research and Innovation Partnership Fund (No. 201703780039).

\section{Disclosure statement}

The authors have declared that there is no conflict of interest. 


\section{References}

Adamu, H. A., Imam, M. U., Ooi, D. J., Esa, N. M., Rosli, R., \& Ismail, M. 2016. Perinatal exposure to germinated brown rice and its gamma amino-butyric acid-rich extract prevents high fat diet-induced insulin resistance in first generation rat offspring. Food \& Nutr. Res. 60(1): 30209.

Adeghate, E., \& Ponery, A. 2002. GABA in the endocrine pancreas: cellular localization and function in normal and diabetic rats. Tissue Cell 34(1): 1-6.

Ahromrit, A., Ledward, D., \& Niranjan, K. 2006. High pressure induced water uptake characteristics of Thai glutinous rice. J. Food Eng. 72(3): 225-233.

Alam, M., Kaur, J., Khaira, H., \& Gupta, K. 2016. Extrusion and extruded products: changes in quality attributes as affected by extrusion process parameters: a review. Crit. Rev. Food. Sci. Nutr. 56(3): 445-473.

An, H. J., \& King, J. M. 2007. Thermal characteristics of ohmically heated rice starch and rice flours. J. Food Sci. 72(1): C084-C088.

Atungulu, G. G., \& Pan, Z. 2014. Rice industrial processing worldwide and impact on macroand micronutrient content, stability, and retention. Ann. NY Acad.Sci. 1324(1): 15-28.

Awad, T. S., Moharram, H. A., Shaltout, O. E., Asker, D., \& Youssef, M. M. 2012. Applications of ultrasound in analysis, processing and quality control of food: A review. Food Res. Int. 48(2): 410-427.

Baek, J. J., \& Lee, S. 2014. Functional characterization of brown rice flour in an extruded noodle system. J. Korean Soc. Appl. Biol. Chem. 57(4): 435-440.

Balasubramaniam, V., Martínez-Monteagudo, S. I., \& Gupta, R. 2015. Principles and application of high pressure-based technologies in the food industry. Annu. Rev. Food Sci. Technol. 6: 435-462.

Barba, F. J., Ahrné, L., Xanthakis, E., Landerslev, M. G., \& Orlien, V. (2018). Chapter 2 Innovative Technologies for Food Preservation Innovative Technologies for Food Preservation (pp. 25-51): Academic Press.

Barba, F. J., Esteve, M. J., \& Frígola, A. 2012. High pressure treatment effect on physicochemical and nutritional properties of fluid foods during storage: a review. Compr. Rev. Food Sci. Food Saf. 11(3): 307-322.

Barba, F. J., Koubaa, M., do Prado-Silva, L., Orlien, V., \& Sant'Ana, A. d. S. 2017a. Mild processing applied to the inactivation of the main foodborne bacterial pathogens: A review. Trends Food Sci. Technol. 66: 20-35.

Barba, F. J., Mariutti, L. R. B., Bragagnolo, N., Mercadante, A. Z., Barbosa-Cánovas, G. V., \& Orlien, V. 2017b. Bioaccessibility of bioactive compounds from fruits and vegetables after thermal and nonthermal processing. Trends Food Sci. Technol. 67: 195-206.

Barba, F. J., Parniakov, O., Pereira, S. A., Wiktor, A., Grimi, N., Boussetta, N., Saraiva, J. A., Raso, J., Martin-Belloso, O., Witrowa-Rajchert, D., Lebovka, N., \& Vorobiev, E. 2015a. Current applications and new opportunities for the use of pulsed electric fields in food science and industry. Food Res. Int. 77: 773-798.

Barba, F. J., Poojary, M. M., Wang, J., Olsen, K., \& Orlien, V. 2017c. Effect of high pressure processing and storage on the free amino acids in seedlings of Brussels sprouts. Innov. Food Sci. Emerg. Technol. 41: 188-192. 
Barba, F. J., Terefe, N. S., Buckow, R., Knorr, D., \& Orlien, V. 2015b. New opportunities and perspectives of high pressure treatment to improve health and safety attributes of foods. A review. Food Res. Int. 77: 725-742.

Bari, M., Nei, D., Enomoto, K., Todoriki, S., \& Kawamoto, S. 2009. Combination treatments for killing Escherichia coli O157: H7 on alfalfa, radish, broccoli, and mung bean seeds. J. Food Prot. 72(3): 631-636.

Bari, M. L., Enomoto, K., Nei, D., \& Kawamoto, S. 2011. Development of effective seed decontamination technology to inactivate pathogens on mung bean seeds and its practical application in Japan. Japan Agric. Res. Q. 45(2): 153-161.

Bartnik, M., \& Szafrańska, I. 1987. Changes in phytate content and phytase activity during the germination of some cereals. J. Cereal Sci. 5(1): 23-28.

Bello, M., Tolaba, M. P., \& Suarez, C. 2004. Factors affecting water uptake of rice grain during soaking. LWT-Food Sci. Technol. 37(8): 811-816.

Boers, H. M., Seijen ten Hoorn, J., \& Mela, D. J. 2015. A systematic review of the influence of rice characteristics and processing methods on postprandial glycaemic and insulinaemic responses. Br. J. Nutr. 114(7): 1035-1045.

Boluda-Aguilar, M., Taboada-Rodrí guez, A., López-Gómez, A., Marín-Iniesta, F., \& Barbosa-Cánovas, G. V. 2013. Quick cooking rice by high hydrostatic pressure processing. LWT-Food Sci. Technol. 51(1): 196-204.

Bourke, P., Ziuzina, D., Boehm, D., Cullen, P. J., \& Keener, K. 2018. The potential of cold plasma for safe and sustainable food production. Trend. Biotechnol. DOI: 10.1016/j.tibtech.2017.11.001.

Cáceres, P. J., Martínez-Villaluenga, C., Amigo, L., \& Frias, J. 2014. Maximising the phytochemical content and antioxidant activity of Ecuadorian brown rice sprouts through optimal germination conditions. Food Chem. 152: 407-414.

Chalermchaiwat, P., Jangchud, K., Jangchud, A., Charunuch, C., \& Prinyawiwatkul, W. 2015. Antioxidant activity, free gamma-aminobutyric acid content, selected physical properties and consumer acceptance of germinated brown rice extrudates as affected by extrusion process. LWT-Food Sci. Technol. 64(1): 490-496.

Chandalia, M., Garg, A., Lutjohann, D., von Bergmann, K., Grundy, S. M., \& Brinkley, L. J. 2000. Beneficial effects of high dietary fiber intake in patients with type 2 diabetes mellitus. N. Engl. J. Med. 342(19): 1392-1398.

Cheevitsopon, E., \& Noomhorm, A. 2011. Effects of parboiling and fluidized bed drying on the physicochemical properties of germinated brown rice. Int. J. Food Sci. Technol. 46(12): 2498-2504.

Cheevitsopon, E., \& Noomhorm, A. 2015. Effects of superheated steam fluidized bed drying on the quality of parboiled germinated brown rice. J. Food Process. Preserv. 39(4): 349-356.

Chen, H., Siebenmorgen, T., \& Griffin, K. 1998. Quality characteristics of long-grain rice milled in two commercial systems. Cereal Chem. 75(4): 560-565.

Chen, H. H. 2014. Investigation of properties of long-grain brown rice treated by low-pressure plasma. Food Bioprocess Technol. 7(9): 2484-2491.

Chen, H. H., Chang, H. C., Chen, Y. K., Hung, C. L., Lin, S. Y., \& Chen, Y. S. 2016. An 
improved process for high nutrition of germinated brown rice production: Low-pressure plasma. Food Chem. 191: 120-127.

Chen, H. H., Chen, Y. K., \& Chang, H. C. 2012. Evaluation of physicochemical properties of plasma treated brown rice. Food Chem. 135(1): 74-79.

Chen, H. H., Hung, C. L., Lin, S. Y., \& Liou, G. J. 2015a. Effect of low-pressure plasma exposure on the storage characteristics of brown rice. Food Bioprocess Technol. 8(2): 471-477.

Chen, Y.-P., Liu, Q., Yue, X.-Z., Meng, Z.-W., \& Liang, J. 2013. Ultrasonic vibration seeds showed improved resistance to cadmium and lead in wheat seedling. Environ. Sci. Pollut. Res. 20(7): 4807-4816.

Chen, Y., Jiang, W., Jiang, Z., Chen, X., Cao, J., Dong, W., \& Dai, B. 2015b. Changes in physicochemical, structural, and sensory properties of irradiated brown Japonica Rice during storage. J. Agric. Food Chem. 63(17): 4361-4369.

Cho, D.-H., \& Lim, S.-T. 2016. Germinated brown rice and its bio-functional compounds. Food Chem. 196: 259-271.

Cho, D.-H., \& Lim, S.-T. 2018. Changes in phenolic acid composition and associated enzyme activity in shoot and kernel fractions of brown rice during germination. Food Chem. 256: 163-170.

Chung, H.-J., Cho, A., \& Lim, S.-T. 2012. Effect of heat-moisture treatment for utilization of germinated brown rice in wheat noodle. LWT-Food Sci. Technol. 47(2): 342-347.

Chung, H.-J., Cho, A., \& Lim, S.-T. 2014. Utilization of germinated and heat-moisture treated brown rices in sugar-snap cookies. LWT-Food Sci. Technol. 57(1): 260-266.

Chung, S., Rico, C., \& Kang, M. 2014. Comparative study on the hypoglycemic and antioxidative effects of fermented paste (Doenjang) prepared from soybean and brown rice mixed with rice bran or red Ginseng Marc in mice fed with high fat diet. Nutrients 6(10): 4610.

Cornejo, F., Caceres, P. J., Martínez-Villaluenga, C., Rosell, C. M., \& Frias, J. 2015. Effects of germination on the nutritive value and bioactive compounds of brown rice breads. Food Chem 173(Supplement C): 298-304.

Coulibaly, A., Kouakou, B., \& Chen, J. 2011. Phytic acid in cereal grains: structure, healthy or harmful ways to reduce phytic acid in cereal grains and their effects on nutritional quality. Am. J. Plant Nutr. Fert. Technol. 1(1): 1-22.

Cui, L., Pan, Z., Yue, T., Atungulu, G. G., \& Berrios, J. 2010. Effect of ultrasonic treatment of brown rice at different temperatures on cooking properties and quality. Cereal Chem. 87(5): 403-408.

Das, M., Banerjee, R., \& Bal, S. 2008a. Evaluation of physicochemical properties of enzyme treated brown rice (Part B). LWT-Food Sci. Technol. 41(10): 2092-2096.

Das, M., Gupta, S., Kapoor, V., Banerjee, R., \& Bal, S. 2008b. Enzymatic polishing of rice-A new processing technology. LWT-Food Sci. Technol. 41(10): 2079-2084.

De Datta, S. 1981. Morphology, growth, and development of the rice plant. Principles and practices of rice production. John Wiley and Sons, New York: 146-172.

Diana, M., Quílez, J., \& Rafecas, M. 2014. Gamma-aminobutyric acid as a bioactive compound in foods: a review. J Funct. Foods 10: 407-420. 
Ding, C., Khir, R., Pan, Z., Zhao, L., Tu, K., El-Mashad, H., \& McHugh, T. H. 2015. Improvement in shelf life of rough and brown rice using infrared radiation heating. Food Bioprocess Technol. 8(5): 1149-1159.

Ding, J., Hou, G. G., Dong, M., Xiong, S., Zhao, S., \& Feng, H. 2018a. Physicochemical properties of germinated dehulled rice flour and energy requirement in germination as affected by ultrasound treatment. Ultrason. Sonochem. 41: 484-491.

Ding, J., Ulanov, A. V., Dong, M., Yang, T., Nemzer, B. V., Xiong, S., Zhao, S., \& Feng, H. 2018b. Enhancement of gama-aminobutyric acid (GABA) and other health-related metabolites in germinated red rice (Oryza sativa L.) by ultrasonication. Ultrason. Sonochem. 40(Part A): 791-797.

Dymek, K., Dejmek, P., Panarese, V., Vicente, A. A., Wadsö, L., Finnie, C., \& Galindo, F. G. 2012. Effect of pulsed electric field on the germination of barley seeds. LWT-Food Sci. Technol. 47(1): 161-166.

Esa, N. M., Kadir, K.-K. A., Amom, Z., \& Azlan, A. 2013. Antioxidant activity of white rice, brown rice and germinated brown rice (in vivo and in vitro) and the effects on lipid peroxidation and liver enzymes in hyperlipidaemic rabbits. Food Chem. 141(2): 1306-1312.

Estrada-Girón, Y., Swanson, B., \& Barbosa-Cánovas, G. 2005. Advances in the use of high hydrostatic pressure for processing cereal grains and legumes. Trends Food Sci. Technol. 16(5): 194-203.

Farkas, J., \& Mohácsi-Farkas, C. 2011. History and future of food irradiation. Trends Food Sci. Technol. 22(2): 121-126.

Gabrić, D., Barba, F., Roohinejad, S., Gharibzahedi, S. M. T., Radojčin, M., Putnik, P., \& Bursać Kovačević, D. 2018. Pulsed electric fields as an alternative to thermal processing for preservation of nutritive and physicochemical properties of beverages: A review. $J$. Food Process Eng. 41(1): e12638.

Gan, R.-Y., Lui, W.-Y., Wu, K., Chan, C.-L., Dai, S.-H., Sui, Z.-Q., \& Corke, H. 2017. Bioactive compounds and bioactivities of germinated edible seeds and sprouts: An updated review. Trends Food Sci. Technol. 59: 1-14.

Gharibzahedi, S. M. T. 2018. Favorite and traditional rice flour-based puddings, breads and pastries in the north of Iran: A review. J. Ethnic Food. DOI:10.1016/j.jef.2018.03.001

Gharibzahedi, S. M. T., Roohinejad, S., George, S., Barba, F. J., Greiner, R., Barbosa-Cánovas, G. V., \& Mallikarjunan, K. 2018. Innovative food processing technologies on the transglutaminase functionality in protein-based food products: Trends, opportunities and drawbacks. Trends Food Sci. Technol. 75: 194-205.

Goffman, F., \& Bergman, C. 2003. Hydrolytic degradation of triacylglycerols and changes in fatty acid composition in rice bran during storage. Cereal Chem. 80(4): 459-461.

Goufo, P., \& Trindade, H. 2014. Rice antioxidants: phenolic acids, flavonoids, anthocyanins, proanthocyanidins, tocopherols, tocotrienols, $\gamma$-oryzanol, and phytic acid. Food Sci. Nutr. 2(2): 75-104.

Grauwet, T., Vervoort, L., Colle, I., Van Loey, A., \& Hendrickx, M. 2014. From fingerprinting to kinetics in evaluating food quality changes. Trends Biotechnol. 32(3): 125-131.

Gujral, H. S., \& Kumar, V. 2003. Effect of accelerated aging on the physicochemical and textural properties of brown and milled rice. J. Food Eng. 59(2): 117-121. 
Hübner, F., \& Arendt, E. K. 2013. Germination of cereal grains as a way to improve the nutritional value: A review. Crit. Rev. Food. Sci. Nutr. 53(8): 853-861.

Hahm, T.-S., Park, S.-J., \& Martin Lo, Y. 2009. Effects of germination on chemical composition and functional properties of sesame (Sesamum indicum L.) seeds. Biores. Technol. 100(4): 1643-1647.

Hashemi, S. M. B., Khaneghah, A. M., Saraiva, J. A., Jambrak, A. R., Barba, F. J., \& Mota, M. J. 2018. Effect of ultrasound on lactic acid production by Lactobacillus strains in date (Phoenix dactylifera var. Kabkab) syrup. Appl. Microbiol. Biotechnol. 102(6): 2635-2644.

Hu, E. A., Pan, A., Malik, V., \& Sun, Q. 2012. White rice consumption and risk of type 2 diabetes: meta-analysis and systematic review. BMJ 344: e1454.

Hu, Z., Tang, X., Liu, J., Zhu, Z., \& Shao, Y. 2017. Effect of parboiling on phytochemical content, antioxidant activity and physicochemical properties of germinated red rice. Food Chem. 214: 285-292.

Huang, H., Wu, S., Lu, J., Shyu, Y., \& Wang, C. 2017. Current status and future trends of high-pressure processing in food industry. Food Control 72: 1-8.

Huang, X., Cai, W., \& Xu, B. 2014. Kinetic changes of nutrients and antioxidant capacities of germinated soybean (Glycine max L.) and mung bean (Vigna radiata L.) with germination time. Food Chem. 143: 268-276.

Huang, Y.-R., Hung, Y.-C., Hsu, S.-Y., Huang, Y.-W., \& Hwang, D.-F. 2008. Application of electrolyzed water in the food industry. Food Control 19(4): 329-345.

Ilowefah, M., Bakar, J., Ghazali, H. M., Mediani, A., \& Muhammad, K. 2015. Physicochemical and functional properties of yeast fermented brown rice flour. J. Food Sci. Technol. 52(9): 5534-5545.

Islam, M., Ud-Din, M. S., \& Haque, M. 2012. Studies on the effect of brown rice and maize flour on the quality of bread. J. Bangladesh Agric. Uni. 9(2): 297-304.

Jaisut, D., Prachayawarakorn, S., Varanyanond, W., Tungtrakul, P., \& Soponronnarit, S. 2009. Accelerated aging of jasmine brown rice by high-temperature fluidization technique. Food Res. Int. 42(5): 674-681.

Jensen, M. K., Koh-Banerjee, P., Hu, F. B., Franz, M., Sampson, L., Grønbæk, M., \& Rimm, E. B. 2004. Intakes of whole grains, bran, and germ and the risk of coronary heart disease in men. Am. J. Clin. Nutr. 80(6): 1492-1499.

Jia, F., Jiang, L., Zhang, Y., Cao, B., \& Zeng, Y. 2016. Optimization of compound enzymes solution pretreatment for improving germinated brown rice yield. Trans. Chin. Soc. Agric. Eng, 32(22): 289-295.

Jiamyangyuen, S., \& Ooraikul, B. 2008. The physico-chemical, eating and sensorial properties of germinated brown rice. J. Food Agric. Environ. 6(2): 119.

Jones, A. R., Mann, K. D., Kuznesof, S. A., Richardson, D. P., \& Seal, C. J. 2017. The whole grain content of foods consumed in the UK. Food Chem. 214: 453-459.

Jongyingcharoen, J. S., \& Cheevitsopon, E. 2016. Development of UV-treated cooked germinated brown rice and effect of UV-C treatment on its storability, GABA content, and quality. LWT-Food Sci. Technol. 71: 243-248.

Kato, T., Katayama, E., Matsubara, S., Omi, Y., \& Matsuda, T. 2000. Release of allergenic 
proteins from rice grains induced by high hydrostatic pressure. J. Agric. Food Chem. 48(8): 3124-3129.

Kim, H. Y., Hwang, I. G., Kim, T. M., Woo, K. S., Park, D. S., Kim, J. H., Kim, D. J., Lee, J., Lee, Y. R., \& Jeong, H. S. 2012. Chemical and functional components in different parts of rough rice (Oryza sativa L.) before and after germination. Food Chem. 134(1): 288-293.

Kim, M. Y., Lee, S. H., Jang, G. Y., Li, M., Lee, Y. R., Lee, J., \& Jeong, H. S. 2015a. Influence of applied pressure on bioactive compounds of germinated rough rice (Oryza sativa L.). Food Bioprocess Technol. 8(10): 2176-2181.

Kim, M. Y., Lee, S. H., Jang, G. Y., Li, M., Lee, Y. R., Lee, J., \& Jeong, H. S. 2017. Changes of phenolic-acids and vitamin E profiles on germinated rough rice (Oryza sativa L.) treated by high hydrostatic pressure. Food Chem. 217: 106-111.

Kim, M. Y., Lee, S. H., Jang, G. Y., Park, H. J., Li, M., Kim, S., Lee, Y. R., Noh, Y. H., Lee, J., \& Jeong, H. S. 2015b. Effects of high hydrostatic pressure treatment on the enhancement of functional components of germinated rough rice (Oryza sativa L.). Food Chem. 166: 86-92.

Knorr, D., Heinz, V., \& Buckow, R. 2006. High pressure application for food biopolymers. Biochim. Biophys. Acta, Proteins Proteomics 1764(3): 619-631.

Komatsuzaki, N., Tsukahara, K., Toyoshima, H., Suzuki, T., Shimizu, N., \& Kimura, T. 2007. Effect of soaking and gaseous treatment on GABA content in germinated brown rice. $J$. Food Eng. 78(2): 556-560.

Koyama, M., \& Kitamura, Y. 2014. Development of a new rice beverage by improving the physical stability of rice slurry. J. Food Eng. 131: 89-95.

Kozuka, C., Yabiku, K., Takayama, C., Matsushita, M., Shimabukuro, M., \& Masuzaki, H. 2013. Natural food science based novel approach toward prevention and treatment of obesity and type 2 diabetes: recent studies on brown rice and $\gamma$-oryzanol. Obes. Res. Clin. Pract. 7(3): e165-e172.

Kumar, L., Brennan, M. A., Mason, S. L., Zheng, H., \& Brennan, C. S. 2017. Rheological, pasting and microstructural studies of dairy protein-starch interactions and their application in extrusion- based products: A review. Starch-Stärke 69(1-2): 1600273.

Kume, T., Furuta, M., Todoriki, S., Uenoyama, N., \& Kobayashi, Y. 2009. Status of food irradiation in the world. Radiat. Phys. Chem. 78(3): 222-226.

Kuno, T., Takahashi, S., Tomita, H., Hisamatsu, K., Hara, A., Hirata, A., Kobayashi, H., \& Mori, H. 2015. Preventive effects of fermented brown rice and rice bran against $\mathrm{N}$-nitrosobis (2-oxopropyl) amine-induced pancreatic tumorigenesis in male hamsters. Oncol. Lett. 10(6): 3377-3384.

Kwofie, E., \& Ngadi, M. 2017. A review of rice parboiling systems, energy supply, and consumption. Renew. Sust. Energ. Rev. 72: 465-472.

Lamberts, L., De Bie, E., Vandeputte, G. E., Veraverbeke, W. S., Derycke, V., De Man, W., \& Delcour, J. A. 2007. Effect of milling on colour and nutritional properties of rice. Food Chem 100(4): 1496-1503.

Lanning, S. B., \& Siebenmorgen, T. J. 2011. Comparison of milling characteristics of hybrid and pureline rice cultivars. Appl. Eng. Agric. 27(5): 787-795.

Lee, S.-W., Kwon, J.-H., Yoon, S.-R., Woo, S.-M., Jang, S.-Y., Yeo, S.-H., Choi, J.-H., \& 
Jeong, Y.-J. 2010. Quality characteristics of brown rice vinegar by different yeasts and fermentation condition. J. Korean Soc. Food Sci. Nutr. 39(9): 1366-1372.

Lee, S., Singh, D., Jang, E. S., Shin, H. W., Moon, B. S., \& Lee, C. H. 2017. Time-resolved comparative metabolomes for Koji fermentation with brown-, white-, and giant embryo-rice. Food Chem. 231: 258-266.

Lee, Y.-M., Kim, S.-A., Lee, I.-K., Kim, J.-G., Park, K.-G., Jeong, J.-Y., Jeon, J.-H., Shin, J.-Y., \& Lee, D.-H. 2016. Effect of a brown rice based vegan diet and conventional diabetic diet on glycemic control of patients with type 2 diabetes: a 12-week randomized clinical trial. PLoS One 11(6): e0155918.

Li, B., Dai, Z., \& Lu, L. 2007. Studies on the optimum condition of brown rice fermentation and its application in lactic acid fermentation. J. Chin. Inst. Food Sci. Technol. 6: 58-63.

Li, C., Oh, S.-G., Lee, D.-H., Baik, H.-W., \& Chung, H.-J. 2017. Effect of germination on the structures and physicochemical properties of starches from brown rice, oat, sorghum, and millet. Int. J. Biol. Macromol. 105: 931-939.

Li, X., Hao, J., Liu, X., Liu, H., Ning, Y., Cheng, R., Tan, B., \& Jia, Y. 2015. Effect of the treatment by slightly acidic electrolyzed water on the accumulation of $\gamma$-aminobutyric acid in germinated brown millet. Food Chem. 186: 249-255.

Liang, J., Han, B.-Z., Nout, M. R., \& Hamer, R. J. 2008. Effects of soaking, germination and fermentation on phytic acid, total and in vitro soluble zinc in brown rice. Food Chem. 110(4): 821-828.

Liao, L. B., Chen, W. M., \& Xiao, X. M. 2007. The generation and inactivation mechanism of oxidation-reduction potential of electrolyzed oxidizing water. J. Food Eng. 78(4): 1326-1332.

Liu, L., Guo, J., Zhang, R., Wei, Z., Deng, Y., Guo, J., \& Zhang, M. 2015. Effect of degree of milling on phenolic profiles and cellular antioxidant activity of whole brown rice. Food Chem. 185: 318-325.

Liu, Q., Zhu, S., Zhang, J., \& Yu, Y. 2017. Effects of parboiling conditions on cooking properties, textural properties and quality characters of germinated brown rice. Trans. Chin. Soc. Agric. Eng. 33(21): 289-297.

Liu, R., He, X., Shi, J., Nirasawa, S., Tatsumi, E., Li, L., \& Liu, H. 2013. The effect of electrolyzed water on decontamination, germination and $\gamma$-aminobutyric acid accumulation of brown rice. Food Control 33(1): 1-5.

Los, A., Ziuzina, D., Akkermans, S., Boehm, D., Cullen, P. J., Van Impe, J., \& Bourke, P. 2018. Improving microbiological safety and quality characteristics of wheat and barley by high voltage atmospheric cold plasma closed processing. Food Res. Int. 106: 509-521.

Lu, Z.-H., Zhang, Y., Li, L.-T., Curtis, R. B., Kong, X.-L., Fulcher, R. G., Zhang, G., \& Cao, W. 2010. Inhibition of microbial growth and enrichment of $\gamma$-aminobutyric acid during germination of brown rice by electrolyzed oxidizing water. J. Food Prot. 73(3): 483-487.

Marti, A., Seetharaman, K., \& Pagani, M. A. 2010. Rice-based pasta: A comparison between conventional pasta-making and extrusion-cooking. J. Cereal Sci. 52(3): 404-409.

McClements, D. J. 1995. Advances in the application of ultrasound in food analysis and processing. Trends Food Sci. Technol. 6(9): 293-299. 
Miller, A., \& Engel, K.-H. 2006. Content of $\gamma$-oryzanol and composition of steryl ferulates in brown rice (Oryza sativa L.) of European origin. J. Agric. Food Chem. 54(21): 8127-8133.

Mir, S. A., Bosco, S. J. D., Shah, M. A., \& Mir, M. M. 2016. Effect of puffing on physical and antioxidant properties of brown rice. Food Chem. 191: 139-146.

Mir, S. A., Bosco, S. J. D., Shah, M. A., Mir, M. M., \& Sunooj, K. V. 2015. Effect of gamma irradiation on physicochemical properties of brown rice. Int. J. Food Eng. 11(4): 563-571.

Misra, N., Pankaj, S., Segat, A., \& Ishikawa, K. 2016. Cold plasma interactions with enzymes in foods and model systems. Trends Food Sci. Technol. 55: 39-47.

Misra, N. N., Koubaa, M., Roohinejad, S., Juliano, P., Alpas, H., Inácio, R. S., Saraiva, J. A., \& Barba, F. J. 2017a. Landmarks in the historical development of twenty first century food processing technologies. Food Res. Int. 97(Supplement C): 318-339.

Misra, N. N., Martynenko, A., Chemat, F., Paniwnyk, L., Barba, F. J., \& Jambrak, A. R. 2017b. Thermodynamics, transport phenomena, and electrochemistry of external field-assisted nonthermal food technologies. Crit. Rev. Food. Sci. Nutr: DOI: 10.1080/10408398.10402017.11287660.

Mok, C. K. 2006. Process for production of brown rice/green tea beverage. Food Eng. Prog. 10: $214-220$.

Moongngarm, A., \& Saetung, N. 2010. Comparison of chemical compositions and bioactive compounds of germinated rough rice and brown rice. Food Chem. 122(3): 782-788.

Mota, M. J., Lopes, R. P., Koubaa, M., Roohinejad, S., Barba, F. J., Delgadillo, I., \& Saraiva, J. A. 2017. Fermentation at non-conventional conditions in food- and bio-sciences by the application of advanced processing technologies. Cri. Rev. Biotechnol. 38(1): 122-140.

Nakayama, T., Nagai, Y., Uehara, Y., Nakamura, Y., Ishii, S., Kato, H., \& Tanaka, Y. 2017. Eating glutinous brown rice twice a day for 8 weeks improves glycemic control in Japanese patients with diabetes mellitus. Nutr. Diabetes 7(5): e273.

Nambi, V. E., Manickavasagan, A., \& Shahir, S. (2017). Rice milling technology to produce brown rice Brown Rice (pp. 3-21): Springer.

Nanri, A., Mizoue, T., Noda, M., Takahashi, Y., Kato, M., Inoue, M., \& Tsugane, S. 2010. Rice intake and type 2 diabetes in Japanese men and women: the Japan Public Health Center-based Prospective Study. Am. J. Clin. Nutr. 29512.

Nissar, N., Wani, S., Hameed, O. B., Wani, T. A., \& Ahmad, M. 2017. Influence of paddy (Oryza sativa) sprouting on antioxidant activity, nutritional and anti-nutritional properties. J. Food Meas. Charact. 11(4): 1844-1850.

Oey, I., Roohinejad, S., Leong, S. Y., Faridnia, F., Lee, P. Y., \& Kethireddy, V. (2016). Pulsed electric field processing: Its technological opportunities and consumer perception. In A. K. Jaiswal (Ed.), Food processing technologies (pp. 447-516). Boca Raton, FL: CRC Press

Oey, I., Van der Plancken, I., Van Loey, A., \& Hendrickx, M. 2008. Does high pressure processing influence nutritional aspects of plant based food systems? Trends Food Sci. Technol. 19(6): 300-308.

Ogawa, S., Takafuji, K., Tsubuku, S., Horie, Y., Ikegawa, S., \& Higashi, T. 2017. Isotope-coded derivatization based LC/ESI-MS/MS methods using a pair of novel 
reagents for quantification of hydroxycinnamic acids and hydroxybenzoic acids in fermented brown rice product. J. Pharm. Biomed. Anal. 142: 162-170.

Ojha, K. S., Mason, T. J., O’Donnell, C. P., Kerry, J. P., \& Tiwari, B. K. 2017. Ultrasound technology for food fermentation applications. Ultrason. Sonochem. 34: 410-417.

Okarter, N., \& Liu, R. H. 2010. Health benefits of whole grain phytochemicals. Crit. Rev. Food. Sci. Nutr. 50(3): 193-208.

Onuma, K., Kanda, Y., Suzuki Ikeda, S., Sakaki, R., Nonomura, T., Kobayashi, M., Osaki, M., Shikanai, M., Kobayashi, H., \& Okada, F. 2015. Fermented brown rice and rice bran with Aspergillus oryzae (FBRA) prevents inflammation-related carcinogenesis in mice, through inhibition of inflammatory cell infiltration. Nutrients 7(12): 5531.

Osafune, T., Ehara, T., \& Ito, T. 2006. Electron microscopic studies on bactericidal effects of electrolyzed acidic water on bacteria derived from kendo protective equipment. Environ. Health Prev. Med. 11(4): 206-214.

Paiva, F. F., Vanier, N. L., Berrios, J. D. J., Pinto, V. Z., Wood, D., Williams, T., Pan, J., \& Elias, M. C. 2016. Polishing and parboiling effect on the nutritional and technological properties of pigmented rice. Food Chem. 191(Supplement C): 105-112.

Park, D.-J., \& Han, J.-A. 2016. Quality controlling of brown rice by ultrasound treatment and its effect on isolated starch. Carbohydr. Polym. 137: 30-38.

Park, H.-Y., Lee, K.-W., \& Choi, H.-D. 2017. Rice bran constituents: immunomodulatory and therapeutic activities. Food Funct. 8(3): 935-943.

Patindol, J., Newton, J., \& Wang, Y. J. 2008a. Functional properties as affected by laboratory-scale parboiling of rough rice and brown rice.J. Food Sci. 73(8): E370-E377.

Patindol, J., Newton, J., \& Wang, Y. J. 2008b. Functional properties as affected by laboratory - scale parboiling of rough rice and brown rice. J. Food Sci. 73(8).

Perez-Ternero, C., de Sotomayor, M. A., \& Herrera, M. D. 2017. Contribution of ferulic acid, $\gamma$-oryzanol and tocotrienols to the cardiometabolic protective effects of rice bran. $J$. Funct. Foods 32: 58-71.

Poojary, M. M., Dellarosa, N., Roohinejad, S., Koubaa, M., Tylewicz, U., Gómez-Galindo, F., Saraiva, J. A., Rosa, M. D., \& Barba, F. J. 2017. Influence of innovative processing on $\gamma$-aminobutyric acid (GABA) contents in plant food materials. Compr. Rev. Food Sci. Food Saf. 16(5): 895-905.

Pottier, L., Villamonte, G., \& de Lamballerie, M. 2017. Applications of high pressure for healthier foods. Curr. Opin. Food Sci. 16: 21-27.

Pramai, P., Hamid, N. A. A., Mediani, A., Maulidiani, M., Abas, F., \& Jiamyangyuen, S. 2017. Metabolite profiling, antioxidant, and $\alpha$-glucosidase inhibitory activities of germinated rice: nuclear-magnetic-resonance-based metabolomics study. J. Food Drug Anal. 26: 47-57.

Pramudya, R. C., \& Seo, H. S. 2018. Using Check-All-That-Apply (CATA) method for determining product temperature-dependent sensory-attribute variations: A case study of cooked rice. Food Res. Int. 105: 724-732.

Prom-u-thai, C., Fukai, S., Godwin, I. D., \& Huang, L. 2007. Genotypic variation of iron partitioning in rice grain. J Sci Food Agr 87(11): 2049-2054.

Puértolas, E., \& Barba, F. J. 2016. Electrotechnologies applied to valorization of by-products 
from food industry: Main findings, energy and economic cost of their industrialization. Food Bioprod. Process 100: 172-184.

Puértolas, E., Koubaa, M., \& Barba, F. J. 2016. An overview of the impact of electrotechnologies for the recovery of oil and high-value compounds from vegetable oil industry: Energy and economic cost implications. Food Res. Int. 80: 19-26.

Qian, J.-Y., Gu, Y.-P., Jiang, W., \& Chen, W. 2014. Inactivating effect of pulsed electric field on lipase in brown rice. Innov. Food Sci. Emerg. Technol. 22: 89-94.

Quagliariello, V., Iaffaioli, R. V., Falcone, M., Ferrari, G., Pataro, G., \& Donsì, F. 2016. Effect of pulsed electric fields-assisted extraction on anti-inflammatory and cytotoxic activity of brown rice bioactive compounds. Food Res. Int. 87: 115-124.

Renzetti, S., \& Arendt, E. 2009. Effect of protease treatment on the baking quality of brown rice bread: from textural and rheological properties to biochemistry and microstructure. J. Cereal Sci. 50(1): 22-28.

Roohinejad, S., Everett, D.W. \& Oey, I. (2014a). Effect of pulsed electric field processing on carotenoid extractability of carrot puree. Int. J. Food Sci. Tech. 49, 2120-2127.

Roohinejad, S., Oey, I., Everett, D.W. \& Niven, B.E. (2014b). Evaluating the effectiveness of b-carotene extraction from pulsed electric field-treated carrot pomace using oil-in-water microemulsion. Food Bioprocess Tech. 7, 3336-3348.

Roohinejad, S, Mirhosseini, H., Saari, N., Mustafa, S., Alias, I, Meor Hussin, A. S., Hamid, A., \& Manap, M.Y.A. 2009b. Evaluation of GABA, crude protein and amino acid composition from different varieties of Malaysian's brown rice. Aust. J. Crop. Sci. 3(4):184-90.

Roohinejad, S., Omidizadeh, A., Mirhosseini, H., Rasti, B., Saari, N., Mustafa, S., Yusof, R. M., Hussin, A.S.M., Hamid, A., \& Manap, M.Y.A. 2009a. Effect of hypocholesterolemic properties of brown rice varieties containing different gamma aminobutyric acid (GABA) levels on sprague-dawley male rats. J. Food Agric. Environ. 7(3-4): 197-203.

Roohinejad, S., Omidizadeh, A., Mirhosseini, H., Saari, N., Mustafa, S., Meor Hussin, A. S., Hamid, A., \& Manap, M.Y.A. 2011. Effect of pre-germination time on amino acid profile and gamma amino butyric acid (GABA) contents in different varieties of Malaysian brown rice. Int. J. Food Prop. 14(6): 1386-1399.

Roohinejad, S., Omidizadeh, A., Mirhosseini, H., Saari, N., Mustafa, S., Yusof, R. M., Hussin, A.S.M., Hamid, A., \& Manap, M.Y.A. 2010. Effect of pre-germination time of brown rice on serum cholesterol levels of hypercholesterolaemic rats. J. Sci. Food Agric. 90 (2): 245-251.

Roselló-Soto, E., Galanakis, C. M., Brnčić, M., Orlien, V., Trujillo, F. J., Mawson, R., Kai, K., Tiwari, B. K., \& Barba, F. J. 2015. Clean recovery of antioxidant compounds from plant foods, by-products and algae assisted by ultrasounds processing. Modeling approaches to optimize processing conditions. Trends Food Sci. Technol. 42(2): 134-149.

Rui, L., Jianxiong, H., Haijie, L., \& Lite, L. 2011. Application of electrolyzed functional water on producing mung bean sprouts. Food Control 22(8): 1311-1315.

Saman, P., Vázquez, J. A., \& Pandiella, S. S. 2008. Controlled germination to enhance the functional properties of rice. Process Biochem. 43(12): 1377-1382.

Schaffer-Lequart, C., Lehmann, U., Ross, A. B., Roger, O., Eldridge, A. L., Ananta, E., Bietry, M.-F., King, L. R., Moroni, A. V., Srichuwong, S., Wavreille, A.-S., Redgwell, R., Labat, 
E., \& Robin, F. 2017. Whole grain in manufactured foods: Current use, challenges and the way forward. Crit. Rev. Food. Sci. Nutr. 57(8): 1562-1568.

Schulze, M. B., Liu, S., Rimm, E. B., Manson, J. E., Willett, W. C., \& Hu, F. B. 2004. Glycemic index, glycemic load, and dietary fiber intake and incidence of type 2 diabetes in younger and middle-aged women. Am. J. Clin. Nutr. 80(2): 348-356.

Schulze, M. B., Schulz, M., Heidemann, C., Schienkiewitz, A., Hoffmann, K., \& Boeing, H. 2007. Fiber and magnesium intake and incidence of type 2 diabetes: A prospective study and meta-analysis. Arch. Intern. Med. 167(9): 956-965.

Segat, A., Misra, N. N., Cullen, P. J., \& Innocente, N. 2016. Effect of atmospheric pressure cold plasma (ACP) on activity and structure of alkaline phosphatase. Food Bioprod. Process 98: 181-188.

Seo, D.-H., Kim, M.-S., Choi, H.-W., Sung, J.-M., Park, J.-D., \& Kum, J.-S. 2016. Effects of millimeter wave treatment on the germination rate and antioxidant potentials and gamma-aminobutyric acid of the germinated brown rice. Food Sci. Biotechnol. 25(1): 111-114.

Shao, Y., Tang, F., Xu, F., Wang, Y., \& Bao, J. 2013. Effects of $\gamma$-irradiation on phenolics content, antioxidant activity and physicochemical properties of whole grain rice. Radiat. Phys. Chem. 85: 227-233.

Shen, S., Wang, Y., Li, M., Xu, F., Chai, L., \& Bao, J. 2015. The effect of anaerobic treatment on polyphenols, antioxidant properties, tocols and free amino acids in white, red, and black germinated rice (Oryza sativa L.). J.Funct. Foods 19(Part A): 641-648.

Sibian, M. S., Saxena, D. C., \& Riar, C. S. 2017. Effect of germination on chemical, functional and nutritional characteristics of wheat, brown rice and triticale: a comparative study. J. Sci. Food Agric. 97: 4643-4651.

Silva, E. S., Roohinejad, S., Koubaa, M., Barba, F. J., Jambrak, A. R., Vukusi'c, T., et al. (2016). Effect of pulsed electric fields on food constituents. In D. Miklavcic (Ed.), Handbook of electroporation (pp. 1-19). Cham: Springer International Publishing.

Sirisoontaralak, P., Nakornpanom, N. N., Koakietdumrongkul, K., \& Panumaswiwath, C. 2015. Development of quick cooking germinated brown rice with convenient preparation and containing health benefits. LWT-Food Sci. Technol. 61(1): 138-144.

Subba Rao, M., \& Muralikrishna, G. 2002. Evaluation of the antioxidant properties of free and bound phenolic acids from native and malted finger millet (Ragi, Eleusine coracana Indaf-15). J. Agric. Food Chem. 50(4): 889-892.

Suhem, K., Matan, N., Matan, N., Danworaphong, S., \& Aewsiri, T. 2015. Improvement of the antifungal activity of Litsea cubeba vapor by using a helium-neon (He-Ne) laser against Aspergillus flavus on brown rice snack bars. Int. J. Food Microbiol. 215: 157-160.

Suhem, K., Matan, N., Nisoa, M., \& Matan, N. 2013a. Inhibition of Aspergillus flavus on agar media and brown rice cereal bars using cold atmospheric plasma treatment. Int. J. Food Microbiol. 161(2): 107-111.

Suhem, K., Matan, N., Nisoa, M., \& Matan, N. 2013b. Low pressure radio frequency plasma effects on the mould control, physical quality, nutritional value, mineral content and trace element content of brown rice snack bars. J. Food Nutr. Res. 52(2): 87-94.

Sultan, N., Wani, I. A., \& Masoodi, F. A. 2018. Moisture mediated effects of $\gamma$-irradiation on 
physicochemical, functional, and antioxidant properties of pigmented brown rice (Oryza sativa L.) flour. J. Cereal Sci. 79: 399-407.

Sung, W.-C. 2005. Effect of gamma irradiation on rice and its food products. Radiat. Phys. Chem. 73(4): 224-228.

Sutharut, J., \& Sudarat, J. 2012. Total anthocyanin content and antioxidant activity of germinated colored rice. Int. Food Res. J. 19(1): 215-221.

Teixeira da Silva, J. A., \& Dobránszki, J. 2014. Sonication and ultrasound: impact on plant growth and development. Plant Cell Tissue Organ Cult. 117(2): 131-143.

Thakur, A. K., \& Gupta, A. K. 2006. Water absorption characteristics of paddy, brown rice and husk during soaking. J. Food Eng. 75(2): 252-257.

Thirumdas, R., Saragapani, C., Ajinkya, M., Deshmukh, R., \& Annapure, U. 2016. Influence of low pressure cold plasma on cooking and textural properties of brown rice. Innov. Food Sci. Emerg. Technol. 37: 53-60.

Ti, H., Zhang, R., Zhang, M., Li, Q., Wei, Z., Zhang, Y., Tang, X., Deng, Y., Liu, L., \& Ma, Y. 2014. Dynamic changes in the free and bound phenolic compounds and antioxidant activity of brown rice at different germination stages. Food Chem. 161:337-344.

Tian, J., Dang, H. N., Yong, J., Chui, W.-S., Dizon, M. P., Yaw, C. K., \& Kaufman, D. L. 2011. Oral treatment with $\gamma$-aminobutyric acid improves glucose tolerance and insulin sensitivity by inhibiting inflammation in high fat diet-fed mice. PLoS One 6(9): e25338.

Tian, S., Nakamura, K., \& Kayahara, H. 2004. Analysis of phenolic compounds in white rice, brown rice, and germinated brown rice. J. Agric. Food Chem. 52(15): 4808-4813.

Torkamani, M. G., Razavi, S. H., \& Gharibzahedi, S. M. T. 2014. Critical quality attributes of Iranian 'Taftoon'breads as affected by the addition of rice bran sourdough with different lactobacilli. Qual. Assur. Saf. Crop. Food. 7(3): 305-311.

Wang, Y., Li, M., Xu, F., Chai, L., Bao, J., \& Shen, S. 2016. Variation in polyphenols, tocols, $\gamma$-aminobutyric acid, and antioxidant properties in whole grain rice (Oryza sativa L.) as affected by different germination time. Cereal Chem. 93(3): 268-274.

Wang, K. M., Wu, J. G., Li, G., Zhang, D. P., Yang, Z. W., \& Shi, C. H. 2011. Distribution of phytic acid and mineral elements in three indica rice (Oryza sativa L.) cultivars. $J$. Cereal Sci. 54(1): 116-121.

Wang, L., Xia, Q., \& Li, Y. 2017a. The effects of high pressure processing and slightly acidic electrolysed water on the structure of Bacillus cereus spores. Food Control 79: 94-100.

Wang, L., Xia, Q., \& Li, Y. 2017b. Synergistic effects of high pressure processing and slightly acidic electrolysed water on the inactivation of Bacillus cereus spores. Int. J. Food Sci. Technol. 52(11): 2429-2435.

Wang, Q., Chen, G., Yersaiyiti, H., Liu, Y., Cui, J., Wu, C., Zhang, Y., \& He, X. 2012. Modeling analysis on germination and seedling growth using ultrasound seed pretreatment in switchgrass. PLoS One 7(10): e47204.

Watchararparpaiboon, W., Laohakunjit, N., \& Kerdchoechuen, O. 2010. An improved process for high quality and nutrition of brown rice production. Food Sci. Technol. Int. 16(2): 147-158.

Wedick, N. M., Sudha, V., Spiegelman, D., Bai, M. R., Malik, V. S., Venkatachalam, S. S., Parthasarathy, V., Vaidya, R., Nagarajan, L., Arumugam, K., Jones, C., Campos, H., 
Krishnaswamy, K., Willett, W., Hu, F. B., Anjana, R. M., \& Mohan, V. 2015. Study design and methods for a randomized crossover trial substituting brown rice for white rice on diabetes risk factors in India. Int. J. Food Sci. Nutr. 66(7): 797-804.

Weickert, M. O., \& Pfeiffer, A. F. H. 2008. Metabolic Effects of Dietary Fiber Consumption and Prevention of Diabetes. J. Nutr. 138(3): 439-442.

Wu, D., Ye, Q., Wang, Z., \& Xia, Y. 2004. Effect of gamma irradiation on nutritional components and $C r y l A b$ protein in the transgenic rice with a synthetic crylAb gene from Bacillus thuringiensis. Radiat. Phys. Chem. 69(1): 79-83.

Wu, F., Chen, H., Yang, N., Wang, J., Duan, X., Jin, Z., \& Xu, X. 2013a. Effect of germination time on physicochemical properties of brown rice flour and starch from different rice cultivars. J. Cereal Sci. 58(2): 263-271.

Wu, F., Yang, N., Chen, H., Jin, Z., \& Xu, X. 2011. Effect of germination on flavor volatiles of cooked brown rice. Cereal Chem. 88(5): 497-503.

Wu, F., Yang, N., Touré, A., Jin, Z., \& Xu, X. 2013b. Germinated brown rice and its role in human health. Crit. Rev. Food. Sci. Nutr. 53(5): 451-463.

Wu, N., Tan, B., Li, S., Tian, X., Liu, M., Liu, Y., Wang, L., \& Zhai, X. 2017. Cooking quality, antioxidant properties, and starch digestibility of wheat noodles substituted with extruded brown rice flour. Cereal Chem. 94(3): 464-470.

Xia, Q., \& Li, Y. 2018a. Mild high hydrostatic pressure pretreatments applied before soaking process to modulate wholegrain brown rice germination: An examination on embryo growth and physicochemical properties. Food Res. Int. 106: 817-824.

Xia, Q., \& Li, Y. 2018b. Ultra-high pressure effects on color, yolatile organic compounds and antioxidants of wholegrain brown rice (Oryza sativa L.) during storage: A comparative study with high-intensity ultrasound and germination pretreatments. Innov. Food Sci. Emerg. Technol. 45: 390-400.

Xia, Q., Mei, J., Yu, W., \& Li, Y. 2017a. High hydrostatic pressure treatments enhance volatile components of pre-germinated brown rice revealed by aromatic fingerprinting based on HS-SPME/GC-MS and chemometric methods. Food Res. Int. 91: 103-114.

Xia, Q., Tao, H., Huang, P., Wang, L., Mei, J., \& Li, Y. 2017b. Minerals in vitro bioaccessibility and changes in textural and structural characteristics of uncooked pre-germinated brown rice influenced by ultra-high pressure. Food Control 71: 336-345.

Xia, Q., Wang, L., \& Li, Y. 2018. Exploring high hydrostatic pressure-mediated germination to enhance functionality and quality attributes of wholegrain brown rice. Food Chem. 249: 104-110.

Xia, Q., Wang, L., Xu, C., Mei, J., \& Li, Y. 2017c. Effects of germination and high hydrostatic pressure processing on mineral elements, amino acids and antioxidants in vitro bioaccessibility, as well as starch digestibility in brown rice (Oryza sativa L.). Food Chem. 214: 533-542.

Xia, Q., Wang, L., Yu, W., \& Li, Y. 2017d. Investigating the influence of selected texture-improved pretreatment techniques on storage stability of wholegrain brown rice: Involvement of processing-induced mineral changes with lipid degradation. Food Res. Int. 99: 510-521.

Xu, J., Zhang, H., Guo, X., \& Qian, H. 2012. The impact of germination on the characteristics of brown rice flour and starch. J. Sci. Food Agric. 92(2): 380-387. 
Yongsmith, B., Thongpradis, P., Klinsupa, W., Chantrapornchai, W., \& Haruthaithanasan, V. 2013. Fermentation and quality of yellow pigments from golden brown rice solid culture by a selected Monascus mutant. Appl. Microbiol. Biotechnol. 97(20): 8895-8902.

You, S.-Y., Oh, S.-G., Han, H. M., Jun, W., Hong, Y.-S., \& Chung, H.-J. 2016. Impact of germination on the structures and in vitro digestibility of starch from waxy brown rice. Int. J. Biol. Macromol. 82: 863-870.

Yu, L., Turner, M. S., Fitzgerald, M., Stokes, J. R., \& Witt, T. 2017a. Review of the effects of different processing technologies on cooked and convenience rice quality. Trends Food Sci. Technol. 59(Supplement C): 124-138.

Yu, Y., Ge, L., Ramaswamy, H., Wang, C., Zhan, Y., \& Zhu, S. 2016. Effect of high-pressure processing on moisture sorption properties of brown rice. Drying Technol. 34(7): 783-792.

Yu, Y., Ge, L., Zhu, S., Zhan, Y., \& Zhang, Q. 2015. Effect of presoaking high hydrostatic pressure on the cooking properties of brown rice. J. Food Sci. Technol. 52(12): 7904-7913.

Yu, Y., Pan, F., Ramaswamy, H. S., Zhu, S., Yu, L., \& Zhang, Q. 2017b. Effect of soaking and single/two cycle high pressure treatment on water absorption, color, morphology and cooked texture of brown rice. J. Food Sci. Technol. 54(6): 1655-1664.

Zeeb, B., McClements, D. J., \& Weiss, J. 2017. Enzyme-based strategies for structuring foods for improved functionality. Annu. Rev. Food Sci. Technol. 8: 21-34.

Zeng, Z., Li, Y., Yang, R., Liu, C., Hu, X., Luo, S., Gong, E., \& Ye, J. 2017. The relationship between reducing sugars and phenolic retention of brown rice after enzymatic extrusion. J. Cereal Sci. 74: 244-249.

Zeng, Z., Luo, S., Liu, C., Hu, X., Gong, E., \& Miao, J. 2018. Phenolic retention of brown rice after extrusion with mesophilic a-amylase. Food Biosci. 21: 8-13.

Zhang, G., \& Hamaker, B. R. 2017. The nutritional property of endosperm starch and its contribution to the health benefits of whole grain foods. Crit. Rev. Food. Sci. Nutr. 57(18): 3807-3817.

Zhang, G., Malik, V. S., Pan, A., Kumar, S., Holmes, M. D., Spiegelman, D., Lin, X., \& Hu, F. B. 2010. Substituting brown rice for white rice to lower diabetes risk: a focus-group study in Chinese adults. J. Am. Diet. Assoc. 110(8): 1216-1221.

Zhang, G., Pan, A., Zong, G., Yu, Z., Wu, H., Chen, X., Tang, L., Feng, Y., Zhou, H., \& Chen, X. 2011. Substituting white rice with brown rice for 16 weeks does not substantially affect metabolic risk factors in middle-aged Chinese men and women with diabetes or a high risk for diabetes. J. Nutr. 141(9): 1685-1690.

Zhang, Q., Xiang, J., Zhang, L., Zhu, X., Evers, J., van der Werf, W., \& Duan, L. 2014. Optimizing soaking and germination conditions to improve gamma-aminobutyric acid content in japonica and indica germinated brown rice. J. Funct. Foods 10: 283-291.

Zhang, R., Khan, S. A., Chi, J., Wei, Z., Zhang, Y., Deng, Y., Liu, L., \& Zhang, M. 2018. Different effects of extrusion on the phenolic profiles and antioxidant activity in milled fractions of brown rice. LWT-Food Sci. Technol. 88: 64-70.

Zhang, X., Wang, L., Cheng, M., Wang, R., Luo, X., Li, Y., \& Chen, Z. 2015a. Influence of ultrasonic enzyme treatment on the cooking and eating quality of brown rice. J. Cereal Sci. 63: 140-146. 
Zhang, Y., Dai, B., Deng, Y., \& Zhao, Y. 2015b. AFM and NMR imaging of squid tropomyosin Tod $\mathrm{p} 1$ subjected to high hydrostatic pressure: evidence for relationships among topography, characteristic domain and allergenicity. RSC Advances 5(89): 73207-73216.

Zhong, Y., Tu, Z., Liu, C., Liu, W., Xu, X., Ai, Y., Liu, W., Chen, J., \& Wu, J. 2013. Effect of microwave irradiation on composition, structure and properties of rice (Oryza sativa L.) with different milling degrees. J. Cereal Sci. 58(2): 228-233.

Zhu, F., Cai, Y.-Z., Bao, J., \& Corke, H. 2010. Effect of $\gamma$-irradiation on phenolic compounds in rice grain. Food Chem. 120(1): 74-77.

Zhu, Z., He, J., Liu, G., Barba, F. J., Koubaa, M., Ding, L., Bals, O., Grimi, N., \& Vorobiev, E. 2016. Recent insights for the green recovery of inulin from plant food materials using non-conventional extraction technologies: a review. Innov. Food Sci. Emerg. Technol. 33: $1-9$.

Zinoviadou, K. G., Galanakis, C. M., Brnčić, M., Grimi, N., Boussetta, N., Mota, M. J., Saraiva, J. A., Patras, A., Tiwari, B., \& Barba, F. J. 2015. Fruit juice sonication: Implications on food safety and physicochemical and nutritional properties. Food Res. Int. 77: 743-752. 


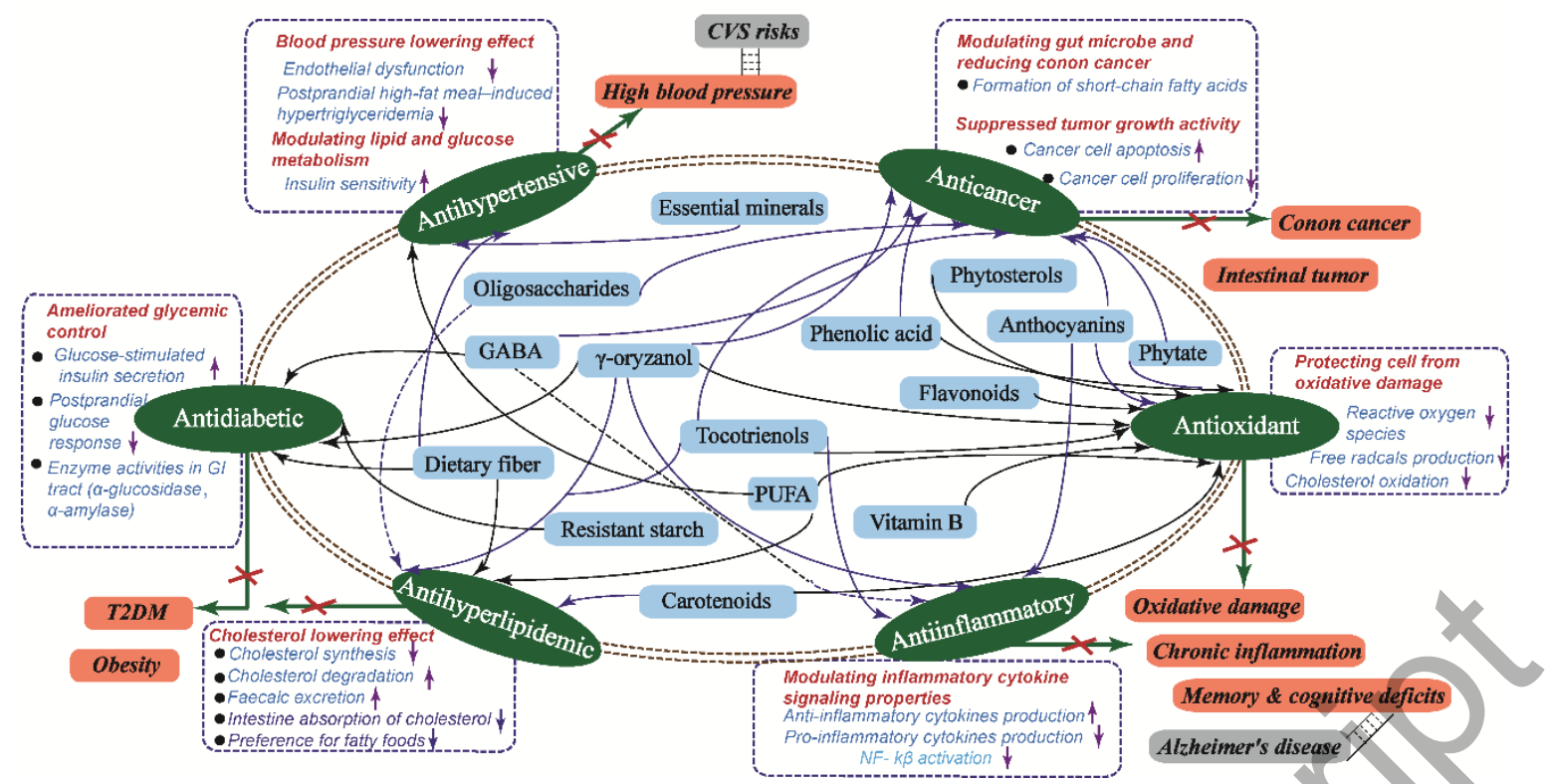

Figure 1. Health benefits and related bioactive components of wholegrain brown rice (WBR). The synergistic action of multiple bioactive components in rice bran (RB) and germ largely contributes to the protective metabolic activities and show the capability to modulate metabolic pathway related to the development of chronic degenerative diseases. Abbreviations: GABA (gamma-aminobutyric acid); PUFA (polyunsaturated fatty acids); CVS (cardiovascular); T2DM (type 2 diabetes mellitus); NF-K $\beta$ (nuclear factor kappa beta); GI (gastrointestinal).

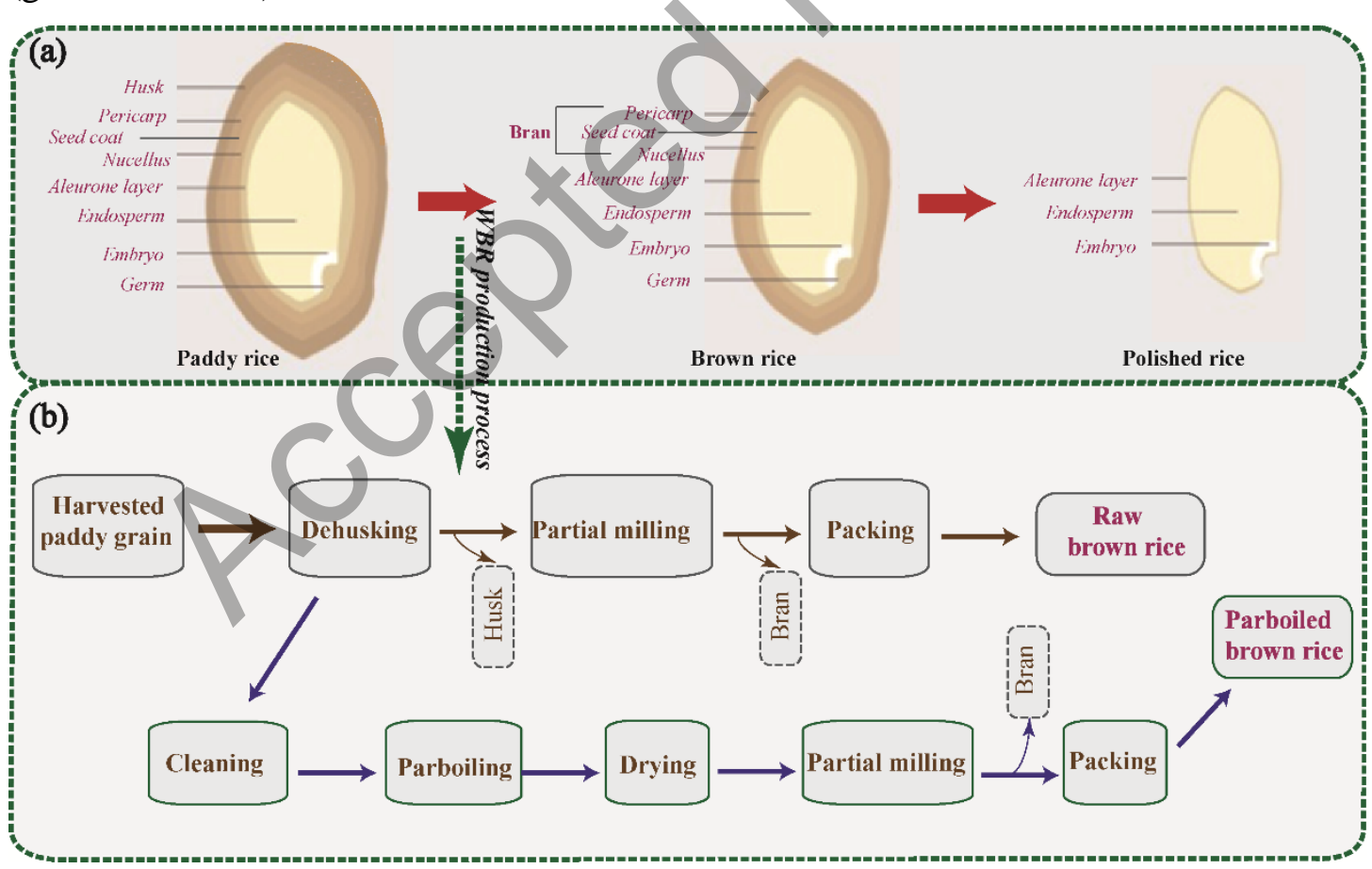

Figure 2. Schematic diagram of wholegrain brown rice (WBR) production: histological composition (a) and the production processes for raw and parboiled WBR grains (b) 


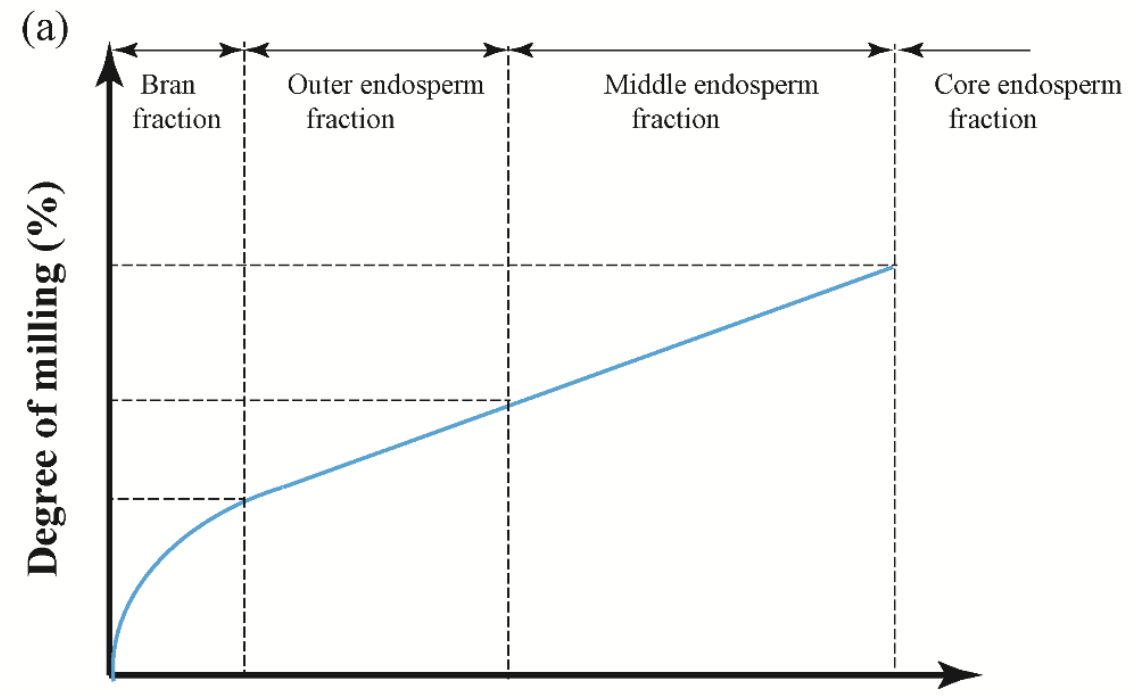

Milling time (s)
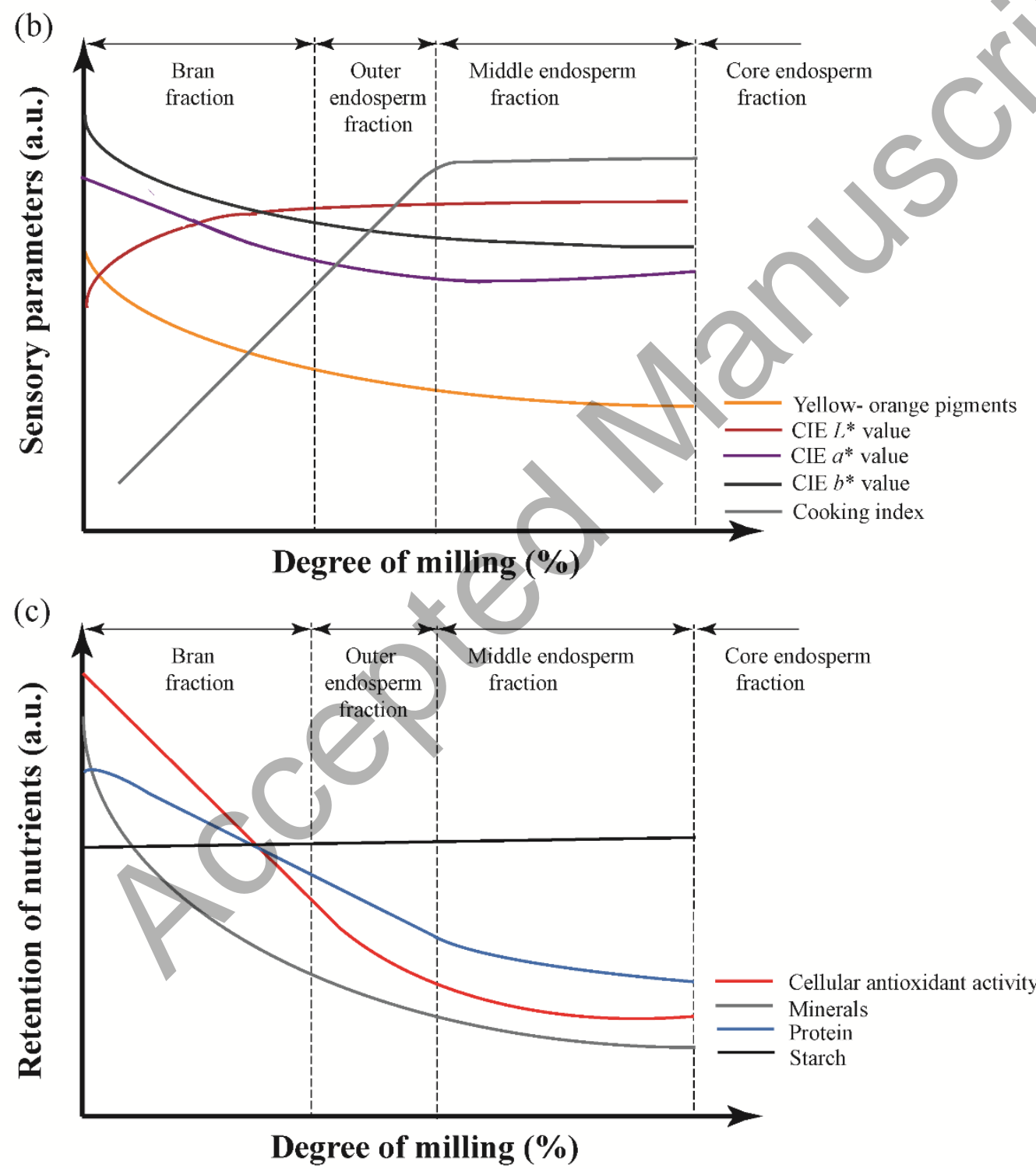

Figure 3. Representative curves showing quantitative relationship between degree of milling $(\mathrm{DOM})$ and physicochemical and nutritional attributes; cooking index $(\mathrm{CI})$ is defined as $\mathrm{CI}=$ 
volume expansion ratio $\times$ length expansion ratio $\times$ water uptake ratio/cooking time, and an increased CI value is desirable

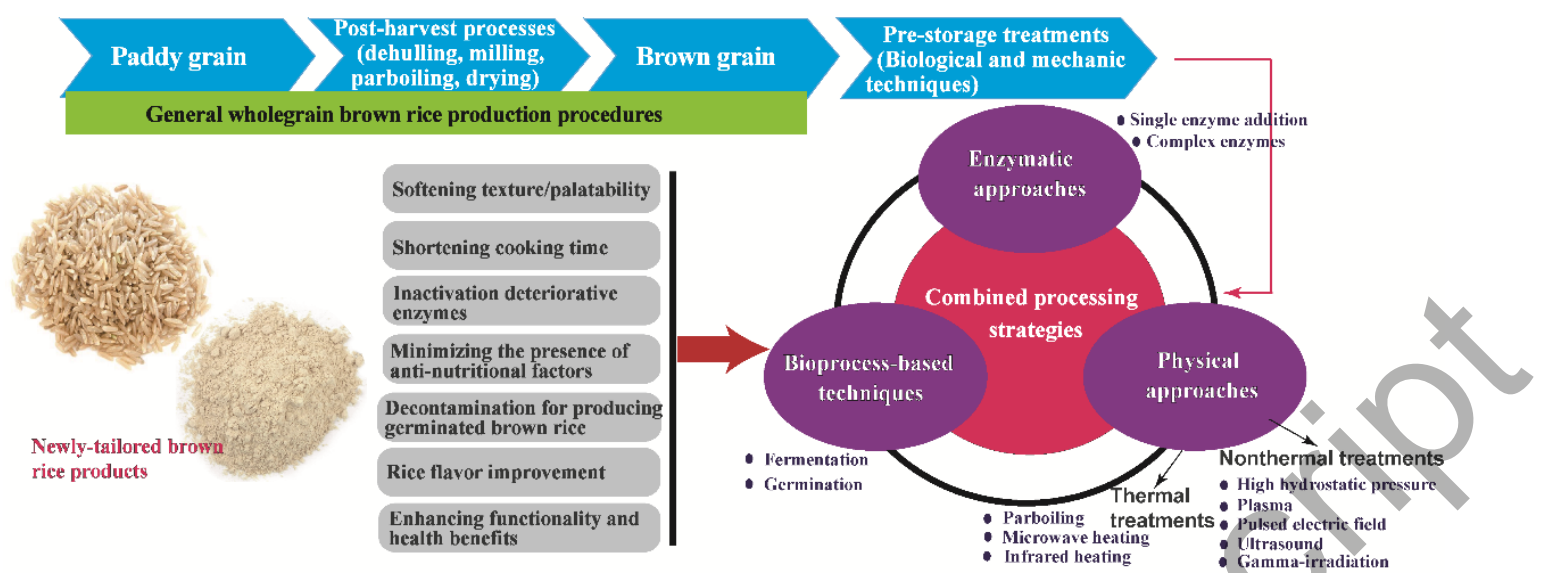

Figure 4. Current challenges and related strategies for wholegrain brown rice (WBR) 
Table 1. A summary of various processing and pretreatment techniques used for wholegrain brown rice (WBR) and their main processing characteristics

\begin{tabular}{|c|c|c|c|c|c|c|}
\hline \multicolumn{2}{|c|}{ Processing approaches } & $\begin{array}{l}\text { Processing conditions } \\
\text { and patterns }\end{array}$ & $\begin{array}{c}\text { Research } \\
\text { purposes/innovations }\end{array}$ & Major findings & $\begin{array}{l}\text { The stages } \\
\text { examined }\end{array}$ & References \\
\hline \multirow[t]{7}{*}{$\begin{array}{l}\text { Bioprocess-based } \\
\text { techniques }\end{array}$} & \multirow[t]{7}{*}{ Germination } & $\begin{array}{l}\text { Soaking with gaseous } \\
\text { treatment at } 35^{\circ} \mathrm{C}\end{array}$ & $\begin{array}{l}\text { Improving the GABA } \\
\text { content by the gaseous } \\
\text { treatment }\end{array}$ & $\begin{array}{l}\text { - GABA contents of GBR increased by changing } \\
\text { gaseous treatment. }\end{array}$ & $\begin{array}{l}\text { Immediately } \\
\text { after soaking }\end{array}$ & $\begin{array}{l}\text { (Komatsuzaki et al., } \\
\text { 2007) }\end{array}$ \\
\hline & & $\begin{array}{l}\text { Water soaking with } \\
\text { different } \mathrm{pH}(3-8), \\
\text { temperature }\left(25-45^{\circ} \mathrm{C}\right) \\
\text { and soaking time } \\
(12-24 \mathrm{~h})\end{array}$ & $\begin{array}{l}\text { Optimizing soaking } \\
\text { conditions for the } \\
\text { improved nutritional } \\
\text { composition }\end{array}$ & $\begin{array}{l}\text { - Germination increased Vitamin B1 and GABA and } \\
\text { reduced phytic acid. } \\
\text { - Compositional variation depended on the soaking } \\
\text { conditions (pH, time, and temperature). } \\
\text { - GBR showed a softer texture than WBR grains }\end{array}$ & $\begin{array}{l}\text { Immediately } \\
\text { after soaking }\end{array}$ & $\begin{array}{l}\text { (Watchararparpaiboon } \\
\text { et al., 2010) }\end{array}$ \\
\hline & & $\begin{array}{l}\text { Soaked at } 28-300^{\circ} \mathrm{C} \text { for } \\
12 \mathrm{~h} \text { and then } \\
\text { germinated within } \\
\text { double layers of cotton } \\
\text { cloth for } 24 \mathrm{~h}\end{array}$ & $\begin{array}{l}\text { Comparing the } \\
\text { compositional } \\
\text { difference between } \\
\text { rough rice and brown } \\
\text { rice after germination }\end{array}$ & $\begin{array}{l}\text { - Higher total FAA, } \alpha \text {-tocopherol, } \gamma \text {-oryzanol, } \\
\text { thiamine, niacin and pyridoxine were found in } \\
\text { germinated rough rice than }\end{array}$ & $\begin{array}{l}\text { Immediately } \\
\text { after } \\
\text { germination }\end{array}$ & $\begin{array}{l}\text { (Moongngarm \& } \\
\text { Saetung, 2010) }\end{array}$ \\
\hline & & & $\begin{array}{l}\text { Evaluating the effects } \\
\text { of germination time } \\
\text { and rice cultivars on } \\
\text { the physicochemical } \\
\text { properties of starch } \\
\text { and rice flour }\end{array}$ & $\begin{array}{l}\text { - Germination caused significant changes in pasting } \\
\text { and rheology of WBR flour but no changes for the } \\
\text { isolated starch as well as starch molecular weight. } \\
\text { - Protein bodies disappeared under the action of } \\
\text { proteolytic enzymes. } \\
\text { - Starch granules became rougher and eroded. }\end{array}$ & $\begin{array}{l}\text { Immediately } \\
\text { after } \\
\text { germination }\end{array}$ & (Wu et al., 2013a) \\
\hline & & $\begin{array}{l}\text { Sterilized by } 0.1 \% \\
\text { NaClO; soaking for } 24 \\
\text { h before germination; } \\
\text { germination } \\
\text { conditions: in } \\
\text { darkness, } 28 / 34{ }^{\circ} \mathrm{C} \text {, } \\
90 \% \text { humidity, and } \\
48 / 96 \mathrm{~h}\end{array}$ & $\begin{array}{l}\text { Exploring health } \\
\text { benefits of sprouts } \\
\text { prepared from } \\
\text { different Ecuadorian } \\
\text { WBR cultivars }\end{array}$ & $\begin{array}{l}\text { - Germination greatly increased GABA, antioxidants } \\
\text { and total phenolic content, depending on genotypes, } \\
\text { germination time and temperature. }\end{array}$ & $\begin{array}{l}\text { Immediately } \\
\text { after } \\
\text { germination }\end{array}$ & (Cáceres et al., 2014) \\
\hline & & $\begin{array}{l}\text { Sterilization: } 0.1 \% \\
\text { NaClO for } 30 \mathrm{~min} \text {; } \\
\text { germination: } 25^{\circ} \mathrm{C} \text { and } \\
5 \mathrm{~d}\end{array}$ & $\begin{array}{l}\text { Examining } \\
\text { germination effects on } \\
\text { the flavor of cooked } \\
\text { WBR }\end{array}$ & $\begin{array}{l}\text { - Germination decreased the characteristic odorants } \\
\text { of WBR grains, depending on germination stages, } \\
\text { rice cultivars, and compound types. }\end{array}$ & $\begin{array}{l}\text { Immediately } \\
\text { after } \\
\text { germination }\end{array}$ & (Wu et al., 2011) \\
\hline & & $\begin{array}{l}\text { Soaking in sterilized } \\
\text { deionized water for } 24 \\
\mathrm{~h} \text { at } 30{ }^{\circ} \mathrm{C} \text {, then } \\
\text { germinated }(48 \mathrm{~h} / 30 \\
\left.{ }^{\circ} \mathrm{C}\right) \text { by spraying water } \\
\text { to maintain moisture }\end{array}$ & $\begin{array}{l}\text { As a blending material } \\
\text { for noodle-making, so } \\
\text { as to utilize nutritional } \\
\text { components of WBR } \\
\text { and reduce abrasive } \\
\text { perception }\end{array}$ & $\begin{array}{l}\text { - The ratio of GBR flour in wheat noodle affected } \\
\text { the hardness, tensile strength, cooking loss and water } \\
\text { absorption of final product. } \\
\text { - Heat-moisture treatment of GBR greatly improved } \\
\text { the texture and cooking quality of the composite } \\
\text { noodles. }\end{array}$ & $\begin{array}{l}\text { After } \\
\text { preparation of } \\
\text { GBR-based } \\
\text { products }\end{array}$ & (Chung et al., 2012) \\
\hline
\end{tabular}




\begin{tabular}{|c|c|c|c|c|c|}
\hline & $\begin{array}{l}\text { Anaerobic treatment } \\
\text { during germination }\end{array}$ & $\begin{array}{l}\text { Applying anaerobic } \\
\text { treatment to enhance } \\
\text { bioactive components } \\
\text { in GBR }\end{array}$ & $\begin{array}{l}\text { - GABA, antioxidant capability, ferulic, } p \text {-coumaric, } \\
\text { and sinapic acids significantly increased, whereas } \\
\text { the FAA contents varied responding to anaerobic } \\
\text { conditions. }\end{array}$ & $\begin{array}{l}\text { Immediately } \\
\text { after } \\
\text { germination }\end{array}$ & (Shen et al., 2015) \\
\hline & $\begin{array}{l}\text { Soaked in an AEW: } 37 \\
{ }^{\circ} \mathrm{C}, 84 \mathrm{~h} \text {; the water was } \\
\text { replaced every } 12 \mathrm{~h}\end{array}$ & $\begin{array}{l}\text { Inhibiting the } \\
\text { microbial growth } \\
\text { during germination by } \\
\text { AEW }\end{array}$ & $\begin{array}{l}\text { - AEW showed higher inhibition rates of microbial } \\
\text { growth than NaClO solution and alkaline } \\
\text { electrolyzed water, with reductions of } 5.38 \text { log } \\
\text { CFU/g. } \\
\text { - GABA was improved by AEW treatment. }\end{array}$ & $\begin{array}{l}\text { Immediately } \\
\text { after } \\
\text { germination }\end{array}$ & (Lu et al., 2010) \\
\hline & $\begin{array}{l}\text { Germinated using } \\
\text { different electrolyzed } \\
\text { water, showing varied } \\
\text { pH, } \\
\text { oxidation-reduction } \\
\text { potential, and available } \\
\text { chlorine levels }\end{array}$ & $\begin{array}{l}\text { Investigating the } \\
\text { effects of electrolyzed } \\
\text { water combined with } \\
\text { other treatments on } \\
\text { GABA, germination } \\
\text { potential and } \\
\text { decontamination }\end{array}$ & $\begin{array}{l}\text { - Sprout growth was promoted by AEW, but } \\
\text { inhibited by AlEW; AEW achieved higher GABA } \\
\text { than AlEW; presoaking and ultrasonic treatments } \\
\text { could enhance electrolyzed water derived advantages }\end{array}$ & $\begin{array}{l}\text { Immediately } \\
\text { After } \\
\text { germination }\end{array}$ & $\begin{array}{l}\text { (Liu et al., 2013); ( } \mathrm{Li} \\
\text { et al., 2015) }\end{array}$ \\
\hline Fermentation & $\begin{array}{l}\text { Fermented flour with } \\
\text { yeasts and } L A B\end{array}$ & $\begin{array}{l}\text { Modifying quality } \\
\text { attributes and } \\
\text { functionality of WBR } \\
\text { by fermentation }\end{array}$ & $\begin{array}{l}\text { - Increased contents of functional components and } \\
\text { reduced phytic acid. } \\
\text { - Sensory characteristics of WBR products were } \\
\text { improved by fermentation. }\end{array}$ & $\begin{array}{l}\text { Immediately } \\
\text { After } \\
\text { fermentation }\end{array}$ & $\begin{array}{l}\text { (Ilowefah et al., 2015); } \\
\text { (Li et al., 2007) }\end{array}$ \\
\hline & $\begin{array}{l}\text { WBR fermentation } \\
\text { using yeast for vinegar } \\
\text { production: agitated } \\
\text { and static culture }\end{array}$ & $\begin{array}{l}\text { As raw materials for } \\
\text { producing vinegars }\end{array}$ & $\begin{array}{l}\text { - Acetic acid fermentation using WBR favored the } \\
\text { accumulation of FAA and GABA. }\end{array}$ & $\begin{array}{l}\text { Immediately } \\
\text { After } \\
\text { fermentation }\end{array}$ & (Lee et al., 2010) \\
\hline & $\begin{array}{l}\text { WBR was inoculated } \\
\text { with } 2 \%(\mathrm{v} / \mathrm{w}) \text { of } \\
\text { Monascus sp.; } \\
\text { incubation: } 15 \\
\text { days } / 28-322^{\circ} \mathrm{C} \\
\end{array}$ & $\begin{array}{l}\text { Solid -state } \\
\text { fermentation of } \\
\text { Monascus sp. using } \\
\text { WBR as substrate }\end{array}$ & $\begin{array}{l}\text { - The higher yellow pigment concentration using } \\
\text { WBR as substrate was obtained compared with other } \\
\text { substrates }\end{array}$ & $\begin{array}{l}\text { Immediately } \\
\text { after } \\
\text { fermentation }\end{array}$ & $\begin{array}{l}\text { (Yongsmith et al., } \\
\text { 2013) }\end{array}$ \\
\hline & $\begin{array}{l}\text { Koji fermentation } \\
\text { using WBR as } \\
\text { substrate by } \\
\text { Aspergillus oryzae }\end{array}$ & $\begin{array}{l}\text { Metabolomic profiles } \\
\text { of Koji fermentation } \\
\text { with WBR as substrate }\end{array}$ & $\begin{array}{l}\text { - WBR Koji showed higher sugars, flavonoid } \\
\text { aglycons and antioxidant activities than white rice }\end{array}$ & $\begin{array}{l}\text { Immediately } \\
\text { After } \\
\text { fermentation }\end{array}$ & (Lee et al., 2017) \\
\hline $\begin{array}{l}\text { Enzymatic } \\
\text { treatments }\end{array}$ & $\begin{array}{l}\text { WBR pretreatments } \\
\text { before cooking using } \\
\text { xylanase and cellulase } \\
\text { enzymes }\end{array}$ & $\begin{array}{l}\text { Degrading bran layers } \\
\text { to improve texture and } \\
\text { cooking performance }\end{array}$ & $\begin{array}{l}\text { - Increased water uptake ratio, volume expansion } \\
\text { ratio with reduced cooking time over untreated WBR } \\
\text { grains }\end{array}$ & $\begin{array}{l}\text { After enzymatic } \\
\text { treatments }\end{array}$ & (Das et al., 2008a) \\
\hline & $\begin{array}{l}\text { Ultrasonic treatments } \\
\left(30 \mathrm{~min} / 40^{\circ} \mathrm{C}\right) \\
\text { followed by the } \\
\text { addition of cellulase } \\
\text { addition }\end{array}$ & $\begin{array}{l}\text { Combining enzyme } \\
\text { use and ultrasound }\end{array}$ & $\begin{array}{l}\text { - Significantly lower hardness, cooking time and } \\
\text { higher taste value as well as more obviously changed } \\
\text { pasting properties in ultrasound-enzyme treated } \\
\text { WBR. }\end{array}$ & $\begin{array}{l}\text { After combined } \\
\text { treatments }\end{array}$ & (Zhang et al., 2015a) \\
\hline & WBR flour was mixed & Combining enzyme & - Enzymatic extrusion contributed to higher retention & After combined & (Zeng et al., 2017); \\
\hline
\end{tabular}




\begin{tabular}{|c|c|c|c|c|c|c|}
\hline & & $\begin{array}{l}\text { with } \alpha \text {-amylase and } \\
\text { then extruded }\end{array}$ & use and extrusion & $\begin{array}{l}\text { of free phenolic acid and total antioxidant activities } \\
\text { than traditional extrusion. }\end{array}$ & treatments & (Zeng et al., 2018) \\
\hline & & $\begin{array}{l}\text { WBR grains were } \\
\text { pretreated by xylanase } \\
\text { and cellulase (pH 5), } \\
\text { then germinated: } 30 \\
{ }^{\circ} \mathrm{C} / 24 \mathrm{~h} \text {, at } 85 \% \\
\text { humidity }\end{array}$ & $\begin{array}{l}\text { Application of } \\
\text { enzymatic treatments } \\
\text { in regulating WBR } \\
\text { germination process }\end{array}$ & $\begin{array}{l}\text { - Enzymes-pretreated WBR shortened } 65 \% \text { of } \\
\text { soaking time, increased germination yields and } \\
\text { GABA contents. }\end{array}$ & $\begin{array}{l}\text { Immediately } \\
\text { after treatment }\end{array}$ & (Jia et al., 2016) \\
\hline \multirow[t]{8}{*}{$\begin{array}{l}\text { Nonthermal } \\
\text { processing } \\
\text { methods }\end{array}$} & \multirow[t]{8}{*}{ HHP } & $\begin{array}{l}\text { HHP treatments: } \\
100-500 \mathrm{MPa} / 10 \mathrm{~min}\end{array}$ & $\begin{array}{l}\text { Enhancing moisture } \\
\text { migration by HHP }\end{array}$ & $\begin{array}{l}\text { - High pressure-mediated changes in WBR } \\
\text { microstructure resulted in better moisture sorption } \\
\text { characteristics. }\end{array}$ & $\begin{array}{l}\text { Immediately } \\
\text { after HHP } \\
\text { processing }\end{array}$ & (Yu et al., 2016) \\
\hline & & $\begin{array}{l}\text { HHP treatments: } \\
\text { 200-600 MPa/0-20 } \\
\min \end{array}$ & $\begin{array}{l}\text { Improving cooking } \\
\text { properties and rice } \\
\text { texture }\end{array}$ & $\begin{array}{l}\text { - Shortening } 20 \text { min of the cooking time; } \\
\text { - Reduced hardness by } 47.8 \% \text { by presoaking and } \\
\text { HHP treatments; } \\
\text { - Damaged structures of pericarp and aleurone layer }\end{array}$ & $\begin{array}{l}\text { Immediately } \\
\text { after HHP } \\
\text { processing }\end{array}$ & (Yu et al., 2015) \\
\hline & & $\begin{array}{l}\text { Soaking }\left(30-500^{\circ} \mathrm{C} / 30\right. \\
\text { min), followed by } \\
\text { one-cyle or two-cycles } \\
\text { HHP treatments } \\
(100-500 \mathrm{MPa} / 10 \mathrm{~min})\end{array}$ & $\begin{array}{l}\text { Evaluating effects of } \\
\text { HHP processing } \\
\text { patterns on WBR } \\
\text { quality properties }\end{array}$ & $\begin{array}{l}\text { - Two-cycle HHP achieved softer texture and lighter } \\
\text { color than one-cycle model. }\end{array}$ & $\begin{array}{l}\text { Immediately } \\
\text { after HHP } \\
\text { processing }\end{array}$ & (Yu et al., 2017b) \\
\hline & & $\begin{array}{l}\text { WBR germination at } \\
37^{\circ} \mathrm{C} \text {, over } 2 \text { or } 6 \\
\text { days, followed by } \\
\text { HHP treatments } \\
(10-100 \mathrm{MP} / 24-48 \mathrm{~h})\end{array}$ & $\begin{array}{l}\text { Enhancing functional } \\
\text { components in GBR } \\
\text { grains }\end{array}$ & $\begin{array}{l}\text { - The contents of total polyphenol, GABA, } \\
\text { arabinoxylan, and } \gamma \text {-oryzanol increased. } \\
\text { - Phytate decreased significantly. }\end{array}$ & $\begin{array}{l}\text { Immediately } \\
\text { after treatment }\end{array}$ & $\begin{array}{l}\text { (Kim et al., 2015a; } \\
\text { Kim et al., 2015b) }\end{array}$ \\
\hline & & $\begin{array}{l}\text { WBR grains were } \\
\text { germinated at } 37^{\circ} \mathrm{C} \\
\text { for } 48 \mathrm{~h} \text {, followed by } \\
\mathrm{HHP} \text { processing } \\
(10-100 \mathrm{MPa} / 24 \mathrm{~h}) \\
\end{array}$ & $\begin{array}{l}\text { Clarifying the impact } \\
\text { of HHP conditions on } \\
\text { the vitamin } E \text { and } \\
\text { phenolic acids in GBR } \\
\text { samples }\end{array}$ & $\begin{array}{l}\text { - Total phenolic acid contents increased with } \\
\text { pressure, while vitamin E contents varied depending } \\
\text { on the pressures }\end{array}$ & $\begin{array}{l}\text { Immediately } \\
\text { after treatment }\end{array}$ & (Kim et al., 2017) \\
\hline & & $\begin{array}{l}\text { WBR germination }(37 \\
\left.{ }^{\circ} \mathrm{C} / 36 \mathrm{~h}\right) \text {, followed by } \\
\text { HHP treatments } \\
(100-500 \mathrm{MPa} / 10 \mathrm{~min})\end{array}$ & $\begin{array}{l}\text { Evaluating the changes } \\
\text { in bioaccessibility of } \\
\text { major nutrients after } \\
\text { WBR germination }\end{array}$ & $\begin{array}{l}\text { - Bioaccessible antioxidants, GABA and free amino } \\
\text { acids increased, while minerals in vitro } \\
\text { bioaccessibility relied on HHP conditions. } \\
\text { - HHP increased starch resistance to enzymatic } \\
\text { hydrolysis. } \\
\text { - Obvious microstructural change in bran fraction at } \\
\text { pressures above } 300 \mathrm{MPa} \text { was observed by AFM. }\end{array}$ & $\begin{array}{l}\text { Immediately } \\
\text { after treatment }\end{array}$ & $\begin{array}{l}\text { (Xia et al., 2017c); } \\
\text { (Xia et al., 2017b) }\end{array}$ \\
\hline & & $\begin{array}{l}\text { WBR germination }(37 \\
\left.{ }^{\circ} \mathrm{C} / 36 \mathrm{~h}\right) \text {, followed by } \\
\mathrm{HHP} \text { treatments } \\
(100-500 \mathrm{MPa} / 10 \mathrm{~min})\end{array}$ & $\begin{array}{l}\text { Revealing the effects } \\
\text { of HHP treatments on } \\
\text { the headspace volatile } \\
\text { compounds in GBR }\end{array}$ & $\begin{array}{l}\text { - HHP showed obvious effects on volatile } \\
\text { fingerprinting of GBR. } \\
\text { - Aldehydes, ketones, and alcohols were increased } \\
\text { by high pressure. }\end{array}$ & $\begin{array}{l}\text { Immediately } \\
\text { after treatment }\end{array}$ & (Xia et al., 2017a) \\
\hline & & $\begin{array}{l}\text { Direct HHP treatments } \\
(150-450 \mathrm{MPa} / 10 \mathrm{~min})\end{array}$ & $\begin{array}{l}\text { Biochemical changes } \\
\text { derived from HHP }\end{array}$ & $\begin{array}{l}\text { - Direct HHP treatments could result in the enhanced } \\
\text { lipid hydrolysis and oxidation and browning }\end{array}$ & $\begin{array}{l}\text { Within storage } \\
\text { process }\end{array}$ & $\begin{array}{l}\text { (Xia et al., 2017d) } \\
\text { (Xia \& Li, 2018b) }\end{array}$ \\
\hline
\end{tabular}




\begin{tabular}{|c|c|c|c|c|c|}
\hline & & $\begin{array}{l}\text { treatments within } \\
\text { storage process }\end{array}$ & phenomenon during storage. & & \\
\hline & $\begin{array}{l}\text { WBR grains were } \\
\text { firstly stressed at } \\
50-350 \mathrm{MPa} / 20 \mathrm{~min}, \\
\text { then germinated }\end{array}$ & $\begin{array}{l}\text { Applying } \\
\text { HHP-induced stress } \\
\text { effects to modulate } \\
\text { WBR functionality } \\
\text { and quality properties }\end{array}$ & $\begin{array}{l}\text { - Stress pressures under } 100 \mathrm{MPa} \text { greatly increased } \\
\text { GABA, in vitro starch digestibility and storability. }\end{array}$ & $\begin{array}{l}\text { Immediately } \\
\text { after treatment }\end{array}$ & (Xia et al., 2018); \\
\hline \multirow[t]{5}{*}{ Plasma } & $\begin{array}{l}\text { Low-pressure plasma } \\
\text { treatments: } 1-3 \mathrm{kV} \\
\text { with constant current } \\
\text { of } 1.2 \mathrm{~mA} \text { for } 30 \mathrm{~min}\end{array}$ & $\begin{array}{l}\text { Changes in } \\
\text { physicochemical } \\
\text { properties of plasma } \\
\text { treated WBR grains }\end{array}$ & $\begin{array}{l}\text { - Reduced cooking time and improved texture and } \\
\text { palatability of cooked WBR samples; } \\
\text { - Modified structure and physicochemical attributes } \\
\text { of starch by plasma treatments }\end{array}$ & $\begin{array}{l}\text { Immediately } \\
\text { after treatment }\end{array}$ & $\begin{array}{l}\text { (Chen et al., 2012); } \\
\text { (Chen, 2014) }\end{array}$ \\
\hline & $\begin{array}{l}\text { Low-pressure plasma } \\
\text { exposure: } 1-3 \mathrm{kV} / 10 \\
\text { min }\end{array}$ & $\begin{array}{l}\text { Evaluating changes in } \\
\text { physicochemical } \\
\text { properties of } \\
\text { plasma-treated WBR } \\
\text { grains }\end{array}$ & $\begin{array}{l}\text { - Cooking time and hardness decreased. } \\
\text { - The activities of } \alpha \text {-amylase and lipoxygenase were } \\
\text { inhibited. } \\
\text { - Higher lipid stability during storage in } \\
\text { plasma-treated WBR samples was found. }\end{array}$ & $\begin{array}{l}\text { Within storage } \\
\text { process }\end{array}$ & (Chen et al., 2015a) \\
\hline & $\begin{array}{l}\text { Atmospheric-pressure } \\
\text { cold plasma: voltage, } \\
10 \mathrm{kV} \text {; flow rate, } 10 \\
\mathrm{~L} / \mathrm{min} \text {; treatment time, } \\
5-25 \text { min; radio } \\
\text { frequency, } 20-40 \mathrm{~W} \\
\end{array}$ & $\begin{array}{l}\text { Inhibiting the } \\
\text { growth of microbes in } \\
\text { WBR using plasma }\end{array}$ & $\begin{array}{l}\text { - Plasma powered at } 40 \mathrm{~W} \text { for } 20 \text { min significantly } \\
\text { inhibited the growth of A. flavus. }\end{array}$ & $\begin{array}{l}\text { During storage } \\
\text { process }\end{array}$ & (Suhem et al., 2013a) \\
\hline & $\begin{array}{l}\text { Low-pressure plasma } \\
\text { treatments }(1-3 \mathrm{kV} / 10 \\
\text { min) followed by } \\
\text { germination process }\end{array}$ & $\begin{array}{l}\text { Using plasma shock to } \\
\text { regulate WBR } \\
\text { germination }\end{array}$ & $\begin{array}{l}\text { - Plasma-pretreated WBR samples showed the } \\
\text { increase in germination performance, GABA levels, } \\
\text { antioxidant activity and } \alpha \text {-amylase activity after } \\
\text { germination. }\end{array}$ & $\begin{array}{l}\text { After } \\
\text { plasma-mediated } \\
\text { germination }\end{array}$ & (Chen et al., 2016) \\
\hline & $\begin{array}{l}\text { PEF treatment } \\
\text { conditions: pulse } \\
\text { width, } 3-15 \mu \mathrm{s} ; \\
\text { frequency, } 50-1000 \\
\mathrm{~Hz} \text {; and voltage, } 0-15 \\
\mathrm{kV}\end{array}$ & $\begin{array}{l}\text { To achieve the lipase } \\
\text { inactivation and obtain } \\
\text { optimum processing } \\
\text { parameters }\end{array}$ & $\begin{array}{l}\text { - The contribution of PEF processing parameters to } \\
\text { inactivate lipase activity was voltage }>\text { frequency } \\
\text { and pulse width }>\text { time. }\end{array}$ & $\begin{array}{l}\text { Immediately } \\
\text { after treatment }\end{array}$ & (Qian et al., 2014) \\
\hline \multirow[t]{2}{*}{ Ultrasound } & $\begin{array}{l}\text { Ultrasonic treatments: } \\
16 \mathrm{kHz}, 2000 \mathrm{~W}, 30 \\
\text { min; and treatment } \\
\text { temperature: } 25,40, \\
\text { and } 55^{\circ} \mathrm{C}\end{array}$ & $\begin{array}{l}\text { To achieve quick } \\
\text { cooking by } \\
\text { ultrasonically treating } \\
\text { WBR grains }\end{array}$ & $\begin{array}{l}\text { - The reduction in cooking time was limited. } \\
\text { - Physicochemical properties of rice flour including } \\
\text { viscosities, crystallinity and thermal behavior were } \\
\text { modified. }\end{array}$ & $\begin{array}{l}\text { Immediately } \\
\text { after treatments }\end{array}$ & (Cui et al., 2010) \\
\hline & $\begin{array}{l}\text { A soaking process }(2-8 \\
\text { h), followed by } \\
\text { ultrasonic treatments: } \\
25^{\circ} \mathrm{C} / 30 \text { min, or } 50 \\
{ }^{\circ} \mathrm{C} / 60 \mathrm{~min} ; 400 \mathrm{kHz} \text {, } \\
\text { and } 185 \mathrm{~W}\end{array}$ & $\begin{array}{l}\text { To improve textural } \\
\text { properties and } \\
\text { examine } \\
\text { physicochemical } \\
\text { changes of isolated } \\
\text { starch from WBR }\end{array}$ & $\begin{array}{l}\text { - Soaking followed by ultrasound promoted water } \\
\text { absorption and texture softening of WBR. } \\
\text { - Pasting and thermal properties and crystalline } \\
\text { structure of starch were changed. }\end{array}$ & $\begin{array}{l}\text { Immediately } \\
\text { after treatment }\end{array}$ & (Park \& Han, 2016) \\
\hline
\end{tabular}




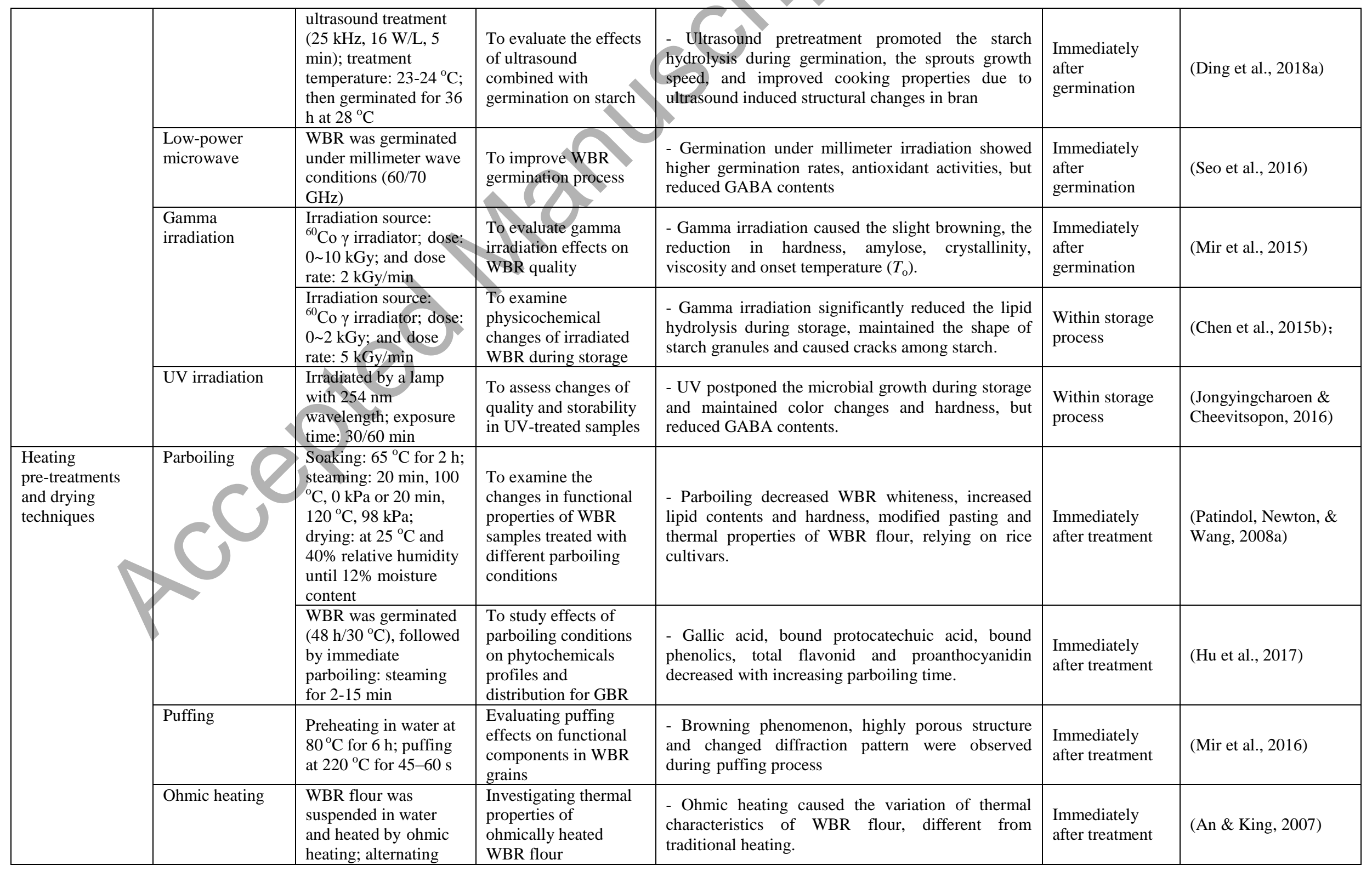




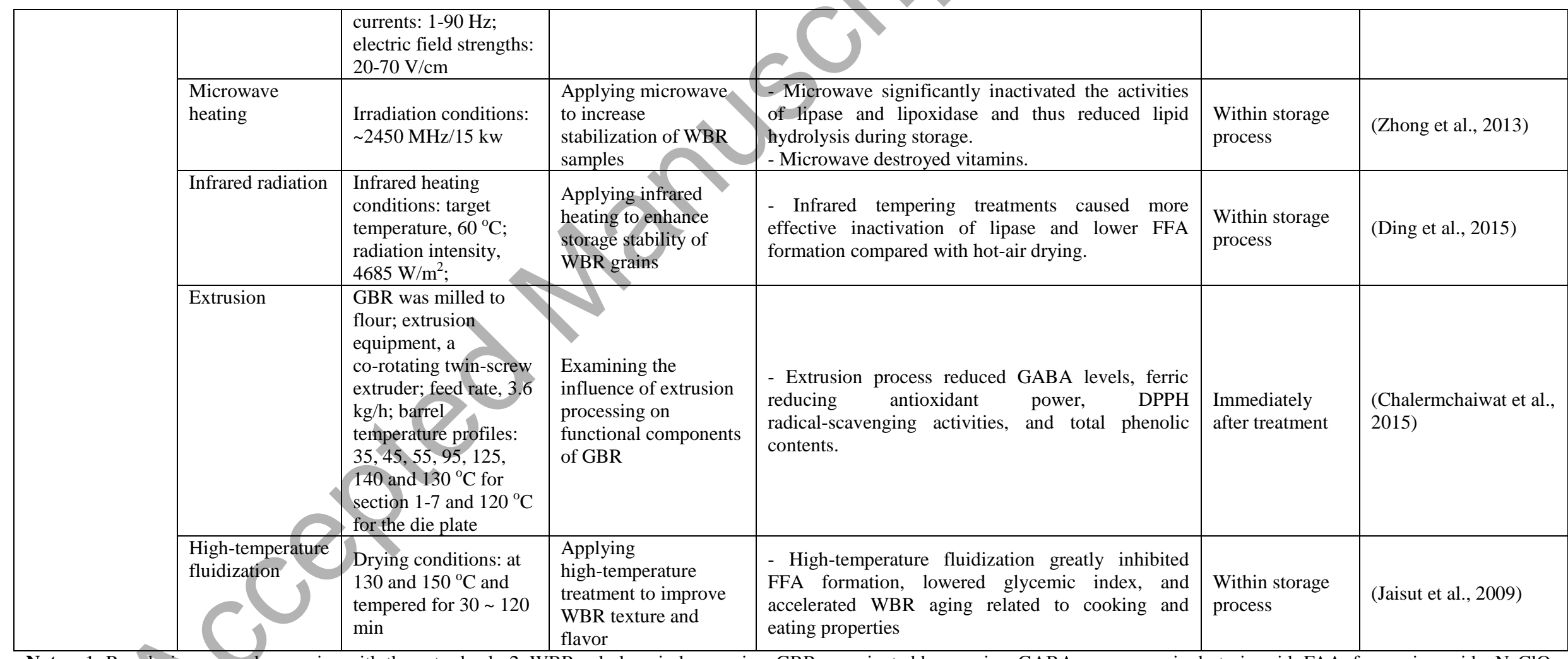

Notes: 1. Rough rice means brown rice with the extra husk; 2. WBR, wholegrain brown rice; GBR, germinated brown rice; GABA, gamma-aminobutyric acid; FAA, free amino acids; NaClO, sodium hypochlorite; AEW, acidic electrolyzed water; AlEW alkane electrolyzed water; LAB, lactic acid bacterial; HHP, high hydrostatic pressure; PEF, pulsed electric filed; UV, ultraviolet; FFA, free fatty acid; AFM, atomic force microscopy; DPPH, 2,2-diphenyl-1-picrylhydrazyl. 
Table 2. Major changes in chemical composition of wholegrain brown rice after germination treatments

\begin{tabular}{|c|c|c|c|c|}
\hline \multicolumn{2}{|c|}{ Chemical substance } & \multirow[t]{2}{*}{$\begin{array}{c}\begin{array}{c}\text { Contents } \\
\text { changes }\end{array} \\
\end{array}$} & \multirow{2}{*}{$\begin{array}{l}\text { Possible response mechanisms and/or health } \\
\text { effects }\end{array}$} & \multirow[b]{2}{*}{$\begin{array}{l}\text { Reference } \\
\text { (Xu et al., } \\
\text { 2012); (Li et } \\
\text { al., 2017); }\end{array}$} \\
\hline $\begin{array}{l}\text { Major } \\
\text { chemical } \\
\text { components }\end{array}$ & Starch & & & \\
\hline & $\begin{array}{l}\text { Non-starch } \\
\text { polysaccharides }\end{array}$ & Decreased & $\begin{array}{l}\text { Polysaccharides Degradation into simpler } \\
\text { compounds (e.g., glucose, fructose and } \\
\text { oligosaccharides) under the action of hydrolytic } \\
\text { enzymes. }\end{array}$ & $\begin{array}{l}\text { (Sibian et al., } \\
\text { 2017) }\end{array}$ \\
\hline & $\mathrm{DF}$ & Increased & $\begin{array}{l}\text { - The increased DF could be related to the } \\
\text { transformation of soluble and insoluble DF } \\
\text { fractions (e.g., inulin, and } \beta \text {-glucans, cellulose, } \\
\text { hemicelluloses, and RS) as well as the formation of } \\
\text { new cell walls during germination. } \\
\text { - GBR with high DF contributes to reducing the } \\
\text { postprandial glucose response and regulating blood } \\
\text { lipids. }\end{array}$ & $\begin{array}{l}\text { (Hübner \& } \\
\text { Arendt, } \\
\text { 2013); (Sibian } \\
\text { et al., 2017) }\end{array}$ \\
\hline & Protein & $\begin{array}{l}\text { Total protein } \\
\text { increased }\end{array}$ & $\begin{array}{l}\text { - Although protein hydrolysis occurs during } \\
\text { germination, protein content can be increased due } \\
\text { to the net synthesis of protein and enzymes in } \\
\text { sprouts }\end{array}$ & $\begin{array}{l}\text { (Moongngarm } \\
\text { \& Saetung, } \\
\text { 2010); (Sibian } \\
\text { et al., 2017) }\end{array}$ \\
\hline & Lipid & Increased & $\begin{array}{l}\text { - The formation of lipid is derived from the } \\
\text { biosynthesis of new compounds within the } \\
\text { germination process. }\end{array}$ & $\begin{array}{l}\text { (Kim et al., } \\
\text { 2012); (Sibian } \\
\text { et al., 2017) }\end{array}$ \\
\hline \multirow[t]{8}{*}{$\begin{array}{l}\text { Minor } \\
\text { bioactive } \\
\text { components }\end{array}$} & GABA & $\begin{array}{l}\text { Increased after } \\
\text { germination; } \\
\text { total content } \\
\text { fluctuate during } \\
\text { germination }\end{array}$ & $\begin{array}{l}\text { - GABA is formed by the decarboxylation of } \\
\text { L-glutamic acid under the catalysis of GAD, and } \\
\text { this process is influenced by GAD activity, } \\
\text { glutamate and physiological states of plant cell }\end{array}$ & $\begin{array}{l}\text { (Zhang et al., } \\
\text { 2014) }\end{array}$ \\
\hline & Phenolics & Increased & $\begin{array}{l}\text {-Germination increased free and bound phenolics, } \\
\text { as well as the contribution of free forms to total } \\
\text { phenolics. } \\
\text { The activation of phenylpropanoid pathway and } \\
\text { the release of cell wall-bound phenolics by } \\
\text { hydrolysis account for the increased antioxidant } \\
\text { activities. }\end{array}$ & $\begin{array}{l}\text { (Cáceres et } \\
\text { al., 2014); (Ti } \\
\text { et al., 2014); } \\
\text { (Tian, } \\
\text { Nakamura, \& } \\
\text { Kayahara, } \\
\text { 2004) }\end{array}$ \\
\hline & Folic acid & & $\begin{array}{l}\text { - Folate deficiencies are related to megaloblastic } \\
\text { anemia, birth defects, the risk of cardiovascular } \\
\text { disease and cancer. }\end{array}$ & $\begin{array}{l}\text { (Sibian et al., } \\
\text { 2017) }\end{array}$ \\
\hline & Vitamin E & Increased & $\begin{array}{l}\text { Physiological metabolic materials (e.g., } \\
\text { tocopherol and tocotrienol) for the WBR seedling } \\
\text { growth are synthesized. }\end{array}$ & $\begin{array}{l}\text { (Kim et al., } \\
\text { 2015b) }\end{array}$ \\
\hline & & $\begin{array}{l}\text { Total contents } \\
\text { were increased }\end{array}$ & $\begin{array}{l}\text { - The content changes are related to vitamin B } \\
\text { biosynthesis due to an increase of enzyme activities } \\
\text { during the germination process. }\end{array}$ & $\begin{array}{l}\text { (Moongngarm } \\
\text { \& Saetung, } \\
\text { 2010); (Kim } \\
\text { et al., 2015b) }\end{array}$ \\
\hline & $\gamma$-Oryzanol & Increased & $\begin{array}{l}\text { - } \gamma \text {-Oryzanol is formed via ester bonds between } \\
\text { ferulic acid and triterpenes; the increase of free } \\
\text { ferulic acid could promote the formation of } \\
\gamma \text {-oryzanol, which is mainly locates in GBR sprouts }\end{array}$ & $\begin{array}{l}\text { (Miller \& } \\
\text { Engel, 2006); } \\
\text { (Kim et al., } \\
\text { 2012) }\end{array}$ \\
\hline & Phytic acid & Decreased & $\begin{array}{l}\text { - The degradation of phytate is catalyzed by } \\
\text { phytase, the activity of which increased during } \\
\text { germination }\end{array}$ & $\begin{array}{l}\text { (Moongngarm } \\
\text { \& Saetung, } \\
\text { 2010); (Kim } \\
\text { et al., 2012) }\end{array}$ \\
\hline & $\begin{array}{l}\text { Anthocyanin and } \\
\text { proanthocyanidin }\end{array}$ & Decreased & $\begin{array}{l}\text { - Attributing to the leaching out of water soluble } \\
\text { fractions during soaking; } \\
\text { - The bound forms with cell wall and proteins can } \\
\text { be hydrolyzed, showing higher diffusion rates }\end{array}$ & $\begin{array}{l}\text { (Sutharut \& } \\
\text { Sudarat, } \\
\text { 2012) }\end{array}$ \\
\hline
\end{tabular}




\begin{tabular}{|c|c|c|c|c|}
\hline & Total flavonoid & Increased & $\begin{array}{l}\text { - Transformation of free and bound forms resulted } \\
\text { in the fluctuation of flavonoid contents; the } \\
\text { percentage contribution of bound flavonoids to } \\
\text { total flavonoid maintained constant after the } \\
\text { germination. }\end{array}$ & $\begin{array}{l}\text { (Ti et al., } \\
2014 \text { ) }\end{array}$ \\
\hline & $\begin{array}{l}\text { Total } \\
\text { antioxidants }\end{array}$ & Increased & $\begin{array}{l}\text { - The increase in total antioxidants is related to the } \\
\text { formation of new compounds presenting } \\
\text { antioxidative effects and the hydrolysis of bound } \\
\text { antioxidants into free forms }\end{array}$ & $\begin{array}{l}\text { (Esa et al., } \\
\text { 2013); (Ti et } \\
\text { al., 2014); } \\
\text { (Xia et al., } \\
\text { 2017c) }\end{array}$ \\
\hline
\end{tabular}

Notes: 1. DF, Dietary fibers; RS, resistant starch; GBR, germinated brown rice; GAD, glutamate decarboxylase; WBR, wholegrain brown rice; GABA, gamma-aminobutyric acid. 


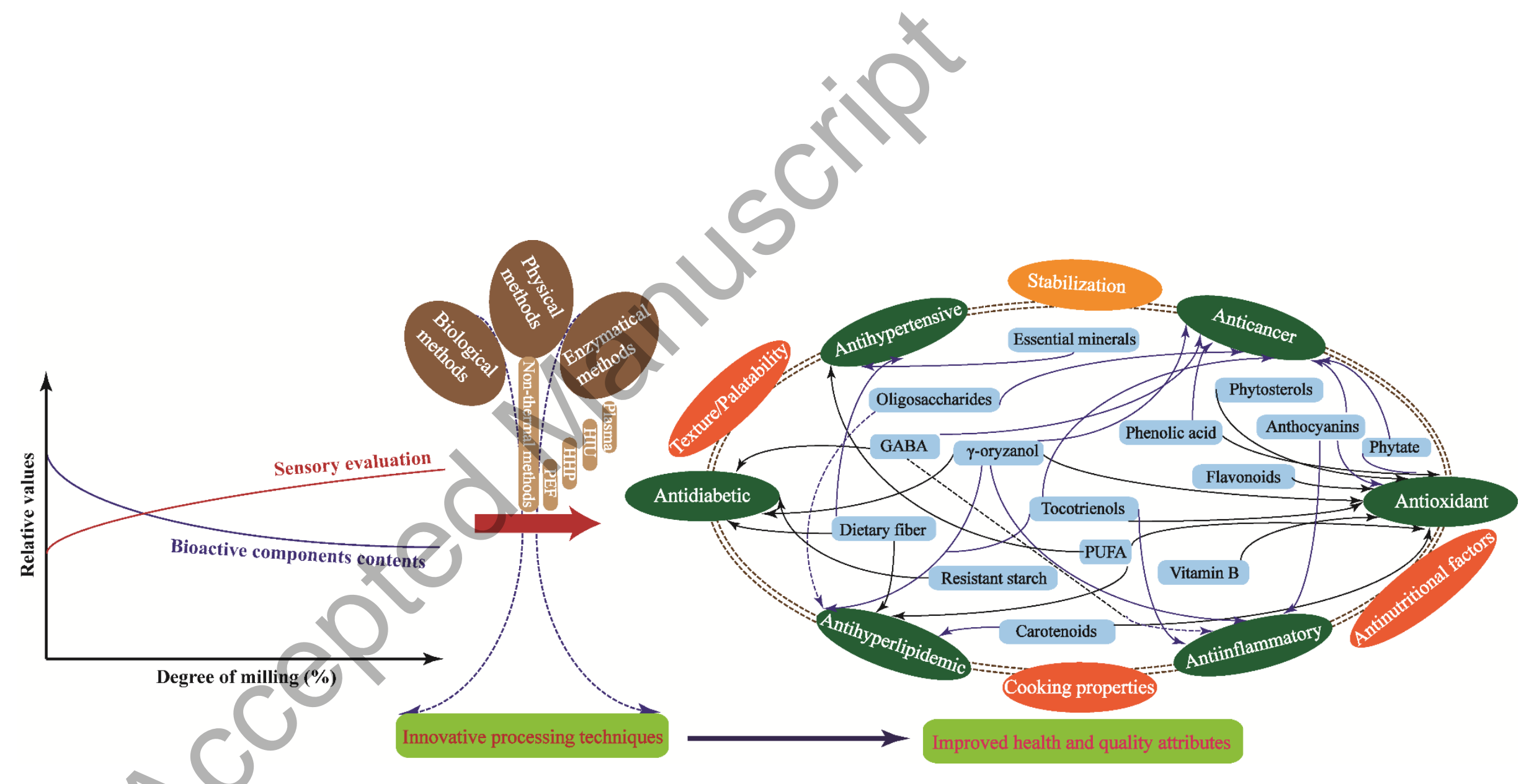

Graphical abstract $(300 \times 300$ DPI $)$ 